\title{
Perceptions and attitudes of Qatar University students regarding the utility of arabic and english in communication and education in Qatar
}

\author{
Eiman Mustafawi ${ }^{1}$ (D) $\cdot$ Kassim Shaaban ${ }^{2} \cdot$ Tariq Khwaileh $^{1} \cdot$ Katsiaryna Ata $^{3}$
}

Received: 19 July 2020 / Accepted: 25 May 2021 / Published online: 2 July 2021

(c) The Author(s) 2021

\begin{abstract}
This study investigates the linguistic attitudes and perceptions of Qatar University students regarding the utility and vitality of the two languages that define the education and communication scenes in Qatar, namely, Arabic and English. It also reports on the predictors of these attitudes in terms of demographic traits. 861 students completed a questionnaire that was divided into: Media Language Preference (MLP); Value and Symbolism of Arabic (VSA); Arabic in Education and Society (AES); Medium of Instruction (MOI); Impact of Al-Jazeera Network (IJN); English in Scientific and Professional Communication (ESPC); Qatari Cultural Identity (QCI); Arabic Books (AB); English in Society and Work (ESW); Language in Workplace (LIW); Arabic in Employment (AE); Status of Arabic (SA); and Manifestations of Sociocultural Identity (MSI). Results showed that Arabic got higher ratings for MLP, VSA, AES, MOI, QCI, and MSI, while English was perceived as more useful than Arabic in ESPC. Correlational analysis showed that Gender had significant correlations with MLP, MOI, ESPC, and MSI, while Nationality, Specialization, and Number of spoken languages had correlations with MLP and MOI.
\end{abstract}

Keywords Language utility · Bilingualism · Medium of instruction · Linguistic perceptions and attitudes

Eiman Mustafawi

eimanmust@qu.edu.qa

Kassim Shaaban

shaaban@aub.edu.lb

Tariq Khwaileh

tariq.khwaileh@qu.edu.qa

Katsiaryna Ata

kp1305447@student.qu.edu.qa

1 Department of English Literature and Linguistics, Qatar University, P.O. Box 2713, Doha, Qatar

2 Department of English, American University of Beirut, 345 Fisk Hall, Beirut, Lebanon

3 Gulf Studies Centre, Qatar University, P.O. Box 2713, Doha, Qatar 


\section{Introduction}

The status of English as an international language has been constantly growing since World War II as a result of the imperial history of Britain and the rising military, economic, and political power of the United States of America. With the advent of globalization, English acquired the status of the language of human, social, and economic development; of research in all fields of knowledge; of modernity, technology, and trade; and of international communication and social media. In brief, countries around the world have started seeing knowledge of English as indispensable for their reform and development plans in all walks of life. In reality, the picture at present in most countries around the world is one of multilingualism and cultural pluralism where different languages and cultures-native, minority, and foreign-interact and work together to help execute policies and plans aiming at improving the welfare of their citizens and the international standing and prestige of these countries. English is seen as a major component of the multilingual structure, moving in many instances from being English as a foreign language (EFL) to encompassing the more vital role of English as medium of instruction (EMI) (Dearden, 2014). These variations in the status of English depend on past historical and political conditions, such as colonialism, ethnic composition, political systems, ideology, and the socioeconomic situation in each country.

Globally, there have been different reasons behind a country's readiness or unwillingness to adopt EMI. For example, many European countries, mostly the Scandinavian states, Germany and the Netherlands, were motivated to join the global community, and considered English an indispensable part of the process. In conformity with the Bologna agreement provisions, European universities opened various programs in English with the aim of commodifying, marketing, and reifying education and making it available to European and non-European citizens, thereby boosting the universities' international rankings (Earls, 2014; Hultgren et al., 2014; Jensen \& Thogersen, 2011; Kuteeva, 2014). In general, Saarinen and Taalas (2017) write about three ways of conceptualization of the internationalization of higher education in the European universities which can be also applied to other countries affected by globalization: internationalization as "a macro (changing global environments), meso (integrating an international dimension to higher education activities) and micro (international publications, staff and student mobility) activity" (p. 599).

Meanwhile, the voices of those who see the expansion of English in the higher education as undesirable, are gaining stronger support. Among the considerations against EMI in many European and Asian countries, for example, was that not all the national students have a good command of academic English, which has negatively affected the ability of students to comprehend what they read as well as the ability to carry meaningful class discussions, and led to poorer student achievement (Haidar \& Fang, 2019; Kirkpatrick, 2012; Wilkinson, 2012). Besides, globally, governments are concerned that EMI can generate controversy in their societies, primarily because English language university education remains available 
mostly to students from elite groups who are able to attend costly private western-run schools while economically marginalized students are deprived of quality education (Barnawi, 2018; Haidar \& Fang, 2019). Last but not least, traditional values and pride in national languages also play a role against EMI, as it could be the case in Nordic countries, famous for their respect for their native languages, utilitarian values, and despise for marketization of education (Doiz et al., 2012; Earls, 2014; Kuteeva, 2014; Saarinen \& Taalas, 2017).

Considering the pros and cons of EMI in the globalizing world, while paying attention to nationalist sentiments, certain governments found nothing better than to adopt policies of parallel instruction in English and national languages. Following these practices, English is to be used in the academic environments together with the native language of each country, and subject-specific terminology is to be translated and aligned between the two languages (Jensen \& Thogersen, 2011; Kuteeva, 2014). The idea, although developed out of 'one-size-fits-all' good intentions is still debatable on the states' level, while the whole concept is considered "rather problematic" to be fully implemented (Saarinen \& Taalas, 2017, p. 600).

As previously mentioned, the focus on the use of more than one language in tertiary education is by no means dictated by the countries' geographical proximity; rather, similar trends are observed in the expanding globalized contexts of South America, Asia, and the Middle East (Barnawi, 2018; Doiz et al., 2012; A. Kirkpatrick et al., 2012; Martin, 2018; Taguchi \& Ishihara, 2018; Takahashi, 2019; Vaish, 2007). Policies of bilingualism, internationalization of higher education, and EMI around the world in general, and the Arab world in particular, have been developed to improve the quality and returns of education in general, and English language education in particular. However, multilingualism here is not restricted to the domain of education; it operates as well in media communication, business and banking workplace, commercial dealings, technology, diplomacy, and international relations (Haberland, 2005; Larsen-Freeman \& Long, 1991).

In many third world countries, the colonial languages have continued to have an impact on communication practices in the administrational, educational, professional, and business fields for a long time after liberation. In fact, many newly-independent Arab and third world countries tried to limit the role of colonial or foreign languages in everyday interaction, education, and administration and impose a one national language policy (Ager, 1996; Findlow, 2006). However, this often came at the expense of indigenous minority languages, such as Berber in North Africa Arab countries, Kurdish in Iraq, and Nubian in Egypt, to name just a few. In all these countries, the foreign languages of the ex-colonizers never lost their prestige and were in constant struggle with the native language over domains of use. Indigenous minorities found in acquiring foreign language proficiency an effective way of carving a place for themselves in such societies (Ager, 1996; Haeri, 2003; Tilmatine, 2015).

These linguistic practices have given rise to arguments, differing points of view, and conflicts in many societies regarding the functions and uses of diverse languages and language varieties in the community. In addition, different viewpoints emerged regarding the role each language plays or should play in administration, daily communication, school and college education, and mass media. Multilingual education 
has also given rise to arguments among scholars, policymakers and laymen alike regarding its impact on socio-cultural and national identity (Babault \& Caitucoli, 1997; Calvet, 1987; Christ, 1997; Mustafawi \& Shaaban, 2019; Shaaban \& Ghaith, 1999; Skutnabb-Kangas \& Toukomaa, 1976).

The language situation in the state of Qatar is characterized by multilingualism, and Arabic diglossia and multidialectism. Diglossia manifests itself in the existence side by side of a formal, mainly written, variety of a language and an informal spoken variety, as defined and illustrated by Ferguson (1959). In the case of Arabic, many spoken varieties are used (Gulf, Levantine, Iraqi, Egyptian, and North African Arabic), each spoken by citizens of the respective regions who come to live and work in the country. Multilingualism, on the other hand, manifests itself clearly in the diversity of languages spoken by Qatari nationals and expatriate communities living in Qatar. As Qatari citizens constitute around 10\% of the population of the country, which is currently around 2.6 million (Planning \& Statistics Authority, 2019), the rest of the population are expatriates coming from various regions of the world with their cultural packages of native languages, customs, values, and traditions that they tend to maintain within their own communities. Depending on the context, daily interaction and communication in Qatari society takes place in multiple languages or language varieties such as English, Qatari Arabic, Standard Arabic, Gulf Pidgin Arabic (Bakir, 2010) with an abundance of code-mixing and code-switching practices.

Like many countries among the developing nations, the state of Qatar has witnessed language-based conflicts revolving around the choice of a medium of instruction, mainly for courses in science, mathematics, and technology in basic and tertiary education (Mustafawi \& Shaaban, 2019). The nature of these conflicts and the language policies that have impacted various sectors of Qatari society in the educational attainment of students and in their sense of national identity have been the subject of examination by different scholars (Al-Mahrooqi et al., 2015; Al-Obaidli, 2009; Belhiah \& Elhami, 2015; Brewer et al., 2007; Ellili-Cherif \& Alkhateeb, 2015; Ellili-Cherif \& Romanowski, 2013; Mustafawi \& Shaaban, 2019; Romanowski et al., 2013; Suleiman, 2013). These and other researchers have attributed the great importance attached to the learning of English in Qatar to the role the British and their language have played in the history of the country and to the worldwide appeal of English as the key to the development of a knowledge-based society in its role of the global language of technology, international communication, expanding multinational companies, and research.

Studies that have addressed the language situation in Qatar have focused on the issues that have arisen during the implementation of the educational reform initiative Education for a New Era (EFNE) introduced in 2003, especially the English Medium of Instruction (EMI) part of that initiative. Some of these issues related to the failure of the move to improve student performance in English as well as in mathematics and science subjects and to the impact of English as a foreign language and as medium of instruction on the national and Islamic cultural identity of Qatari students. The 2012 decision to abandon EMI and go back to Arabic as medium of instruction (AMI) was a bold decision by Qatari authorities in an attempt to remedy the situation and avoid the pitfalls that have plagued the implementation of EFNE. 
The decision, however, has not laid this issue to rest. Thus, while many Qataris have hailed the decision as a victory for the national language and the social and cultural values associated with it, many have questioned the decision and felt it was taken too soon before the EMI experiment had been fully implemented and that the alternative does not come up with a clear plan and, thus, might end up recreating the pre-2003 scene that was the main reason for introducing EFNE (Paschyn, 2013).

These language policy changes and practices have affected the status and prestige of Arabic and English as well as the perceptions of language users of the utility and vitality of these two languages and their roles in Qatari society. In a way, the proponents of differing stands on the issues still oppose one form or another of these policy and practice changes when it does not favor their preferred language choices. It is in the context of unsettled disputes that the present study was designed to examine the linguistic practices and perceptions of Qatar University students regarding the utility and vitality of the Arabic and English languages in the hope that the findings may shed light on intergroup behavior and the implications for the multilingual situation in Qatar.

The present study is an attempt to fill that missing gap in knowledge by surveying the linguistic perceptions and attitudes of Qatar University students and the impact of the variables of gender, residential area, income, nationality, field of specialization, years of study, and number of languages spoken on these attitudes and perceptions.

More specifically, the present study aims to seek answers for the following questions:

1. What are the participants' perceptions of the utility and vitality of Arabic and English in various social, educational and business domains?

2. Are there significant differences in the perceptions of the utility of Arabic and English across the variables of gender, income, area of residence, nationality, field of specialization, years of study, and numbers of languages spoken?

\section{Conceptual framework}

The conceptual framework adopted in this study for the analysis of data is the framework proposed by Dafouz and Smit (2016) for analyzing English-Medium Education in Multilingual University Settings (EMEMUS). EMEMUS, which addresses issues related to English medium instruction (EMI) in higher education in multilingual contexts, consists of six components summarized in the acronym ROADMAPPING which stands for Roles of English (RO), Academic Disciplines (AD), Management (M), Agents (A), Processes and Practices (PP), and Internationalization and Globalization (ING). Research adopting this model would "describe, analyze, and compare EMEMUS within and across contexts" (Dafouz \& Smit, 2016, p. 411). It has an ecological orientation that takes into account the contextual and environmental factors that may impact EMI. Furthermore, it uses discourse as the main point of access and stresses the intersection of the six components and the inherently complex nature of each. 
The component Role ( $R O$ ) sees English as the language of workplace and of better employment, but many understand the native tongue as a key player in the education process, thus rendering the role of English as a dynamic one where English overlaps and shares functions with other languages. The component Academic Disciplines $(A D)$ treats the extent of EMI use as depending greatly on the discipline. Thus, students of Natural Science, Quantitative Science, Engineering, Medicine and Business need higher levels of proficiency in English than Humanities and Social sciences to pursue their studies and to function effectively in the workplace later. Needless to say, EMI requires well-prepared teachers and students with good command of English to become a reality (Dafouz \& Smit, 2016).

The component Language Management $(M)$ refers to language policies and decisions that could come from the government ministries, from language planning outfits, from the private sector, or from the agents on the ground (administrators, faculty, staff, and students). This component needs a great degree of coordination among the various levels for it to bear fruits, and it is an example of the complexity of the processes involved in implementing EMI in higher education. The component Agents (A) points to the multiple agents naturally involved in the planning, implementation, and assessment of language policies in higher education institutions. Agents could include individual actors such as faculty, students, and administrators as well as collective or institutional actors such as colleges, provost offices, and student unions (Dafouz \& Smit, 2016). Language policy studies have emphasized the view that no individual or collective agency is completely autonomous and that policy decisions are affected by global, regional, national and local forces (Marginson \& Rhoades, 2002; Saarinen \& Ursin, 2012).

The component Practices and Processes (PP) refers to particular ways of thinking about and taking action with regards to teaching and learning activities that impact and are impacted by certain EMEMUS contextual realities. EMEMUS draws on the social constructivist theory of learning where in classroom the discursive practices function as an analytical window onto the acquisition and construction of knowledge (Mahn \& John-Steiner, 2012). In multilingual contexts, "these practices reveal the localized process of developing a shared repertoire appropriate to the academic and social communicative purposes which arise from drawing on English in its roles as a disciplinary and educational language and also as a lingua franca" (Dafouz \& Smit, 2016, p. 407).

Finally, the component Internationalization and Glocalization (ING) is associated with the way that higher education institutions deal with the tensions and the synergies between their multifaceted roles in society. For universities to prosper and thrive in a globalized world, they need to consider both global and local forces, such as catering to needs and interests of international students at the global level and to those of minoritized communities locally. This process, called glocalization by Robertson (2018), requires that universities maintain a balance between the two clashing but also interrelated forces that interact and struggle. In practical terms, this component encourages the creation of multilingual and multicultural learning environments and the establishment of research collaboration, professional associations, and faculty and student exchange. It is important to highlight the interaction among the components of Management, Agents' ideolog(ies) and Practices and Processes 
in the process of implementation of EMI. Besides, EMEMUS views Discourse as the intersecting point of entry and access to all six dimensions for examination and evaluation purposes, and which usually comes in the form of language education and language use policy statements and declarations expressed either verbally or in writing (Dafouz \& Smit, 2016).

On top of that, EMEMUS draws on a variety of social and linguistic theories that preceded it, such as critical applied linguistics that deals with the connection between language behavior and power dynamics in language choice and language use (Fairclough, 1995; Jaworski \& Coupland, 2006; Pennycook, 2010; Phillipson, 1992; Tollefson, 2008; Wodak et al., 2002). Besides, it exploits the notions of linguistic rights and language ecology (Benson, 2008; Cummins, 2009; May, 2005) which focus on student empowerment through "collaborative power relations ... relying on linguistic and cultural diversity instead of destroying it by adopting the official discourse of dominant groups" (Despagne, 2010, pp. 71-72).

The application of the EMEMUS framework to the Qatari EMI language policy (2003-2012) provides a detailed critique of the perceived merits and shortcomings of the policy. The critique will include the rationale for adopting EMI and the failure of the policy to deliver the promised improvements in academic achievement; its failure to provide equal access to quality education to all and the consequent discrimination against low socioeconomic groups, mainly in public educational institutions; and its failure to expect and address the opposition by the immediate stakeholders and the general public on ideological grounds or due to practical issues of implementation. It tries to explore the reasons for the failure of a policy that decision makers in Qatar had formulated with the best of intentions and provided those in charge of implementation with all the asked-for and needed resources. It also underscores the role of preparedness and planning in proper implementation and the importance of the involvement of stakeholders in all the stages from planning to execution.

\section{Review of related literature}

\section{Definitions of terms}

Before getting into the review of the literature, the definitions of key concepts referred to in this study are presented below.

Ethnolinguistic vitality: It is "that which makes a group likely to behave as a distinctive and active collective entity in intergroup situations" (Giles et al., 1977, p. 308). Ethnolinguistic vitality of a group or community is its ability to maintain and protect its social presence as a collective entity with a unique cultural identity and its own language. Ehala (2010) offers a more elaborate explanation of the notion of vitality, stating that "vitality depends on the perception of the group strength in comparison with other groups, ... the commitment of its members to the maintenance of the heritage values, their cultural distinctiveness and closedness of their social networks, as well as the level of perceived intergroup discordance" (p.363). 
Language perceptions: Different fields of study such as philosophy, psychology, education, and management have associated the concept perception with "feelings, beliefs, experiences, preferences, mental images, values, concepts, heuristics, stereotypes, and knowledge" (Lara Herrera, 2015, p. 109). Griggs (2014) suggests that while we get the knowledge about the world around us through our senses, the interpretation of this knowledge is done through our perception. In the same vein, Wiesing (2016) provides the following definition: "Perception is process of interpretation. ... The perceived object is therefore an interpretive construct, that is a construction made by the subject through the act of interpretation" (p. 23). Similarly, da Silva (2005) states that "perception refers to the entire sequence from initial sensations, which involve registering and coding of various stimuli perceived by the sensory organs, to the full experience of understanding" (p. 2). Garrett et al. (2003) intheir turn describe perception as "a differentiated set of social meanings,organized as variable value-ratings attaching to ... social attractiveness andto scholastic success" (p. 175).

Language attitudes: Linguistic attitudes have been defined by Ryan and Giles (1982) as "any affective, cognitive or behavioral index of evaluative reactions towards different language varieties or their speakers" (p. 7). Likewise, Dewaele and Pena Diaz (2018) identify linguistic attitudes as "speakers' opinions, ideas and prejudices about a language" (p. 35). Edwards (1982) suggests that peoples' attitudes towards a language or a language variety reveal a great deal about their perceptions of the speakers of that language or language variety. Similarly, Gardner (1985) expresses the view that if we know learners' attitudes toward the target language speakers, then we may be able to predict how they will behave toward them. Apart from that, Garrett et al., (2003) consider language attitudes as "stereotyped responses to community-bound ways of speaking, to discourse styles as well as to dialect varieties in the conventional sense" (p. 5). Speaking of surveys of language attitudes and perceptions, researchers imply here data collection instruments that help gather information on people's sentiments about a particular language, bilingualism and code-switching, and how such beliefs in certain circumstances affect an individual's language choice and a community's view on language shift (Romaine, 1995; Saville-Troike, 2002).

Below we present the review of the literature on the various topics related to the current study.

\section{Coexistence of English and the native languages in the global context}

Studies on language use in tertiary education in the globalized contexts of European and Asian countries vary. While many countries try to follow the call of our times and implement EMI that opens their universities to wider audiences, both among highly qualified students and academic faculty. The arguments of those who condemn the dominance of English in schools and universities are also thoroughly developed and should be taken into consideration.

The studies on EMI in Scandinavian countries are manifold. In Sweden, many studies are done on the attitudes of faculty, students and staff of Swedish 
universities towards the parallel use of English and Swedish in education, respect for linguistic rights and protection of the Swedish language (Airey \& Linder, 2008; Bolton \& Kuteeva, 2012; Brock-Utne, 2001; Hultgren et al., 2014). In this regard, based on the online questionnaires of 668 academic staff and 4524 students at a major Swedish university, Kuteeva (2014) states that the proclaimed 'one-size-fits-all' language policy is not implemented as it was initially planned, and "to this day it largely remains an unoperationalized political slogan" (p. 333). The survey reveals that English is used differently across various disciplines, and the proportion of $\mathrm{PhD}$ theses written in English in the sciences is as high as $94 \%$, while in the social sciences and humanities it is $65 \%$ and $37 \%$ respectively. Although the majority of scholarly papers that are required readings for students are published in English, many Swedish students, however, express dissatisfaction with the parallel language use, claiming among the reasons for supporting monolingualism "difficulties of switching between the two languages and the extra time required to learn content in both languages" (Kuteeva, 2014, p. 340).

The same situation is observed in Denmark. Jensen and Thogersen (2011) also report the growing number of publications in English. Benefitting from the previous studies, scholars notice that in 1990 the number of scholarly articles published in English in the University of Copenhagen (UC) was as high as 65\%, and by the year of 2007 , it rose to more than $95 \%$. Similarly, as the surveys conducted among 1131 UC professors show, respondents express concern over the diminishing prestige of the national Danish language and the established exclusiveness of English, but express positive attitudes towards internationalization in general.

Using the example of internationalization in the Maastricht university in the Netherlands, Wilkinson (2012) shows how the Dutch authorities pursue the goal of reviving the monarchy's status as a trading state "as if in an endeavour to replicate the success of the Dutch hold on the world flower market" (p. 12). With all the benefits that the globalization and internationalization in universities brings to the Dutch economy, the scholar notices that the talks about the Dutch language losing its prestige and about the overall linguistic impoverishment are gaining more prominence in the society. Apart from that, Wilkinson (2012) writes that EMI generates controversy in the kingdom in that the Dutch universities graduates will belong to the well-paid elite "in a way that differentiates them from the others of society" (p. 20).

In general, in the paper dedicated to the analysis of language legislation policies in European universities, Saarinen and Taalas (2017) conclude that Northern European countries offer more university programs in English than the rest of the continent. Netherlands, Finland, and Denmark are on top, followed by Slovakia, Norway and Sweden.

Similarly, in Pakistan, once a British colony, the attitudes towards English are also divided. Haidar \& Fang (2019) mention that English is mostly associated with the elite who use it as their first language due to the class-segregated schooling system, thus exacerbating the social tensions in society. Other groups in the state oppose using English due to the nationalist sentiments which invoke memories of the colonial past, and support using national languages, especially Urdu, as symbol of national and religious identity. Haidar \& Fang (2019) meanwhile notice that 
there is also a third group in Pakistani society who use English as a communication medium without considering its socio-political and cultural dimensions.

\section{The Arab context}

As elsewhere in the world, studies conducted in the Arab region in general, and in the Gulf Cooperation Council (GCC) countries in particular, on which language to use as medium of instruction in higher education institutions, the mother tongue or the foreign language, show little agreement on the issue. Some researchers highlighted the vital perception of learners and other stakeholders of the inter-relatedness of language, identity, and culture where degrading the role of the native language could adversely affect perceptions of the value, status, utility, and vitality of the language and its concomitant cultural and national character and identity (Al-Dabbagh, 2005; Jenkins, 2007; Karmani, 2005a, b; Kramsch, 1998; Shaaban \& Ghaith, 2002, 2003; Suleiman, 2013). That is because the developing gap between the knowledge acquired through the medium of English with its western cultural overtones and the Arab and Islamic culture is reason for concern (Badry \& Willoughby, 2015; Fassi-Fehri, 2013; Hopkyns, 2016; MacLeod \& Abou-El-Kheir, 2017). On the other hand, other studies show that many students and faculty prefer EMI to AMI. AlJarf (2004), Malallah (2000), and Troudi and Jendli (2011) found that students who adopt this stance believe that studying in English is the gate to success in acquiring knowledge in professional fields and in science, business, and technology and to securing better careers in the globalized job market.

The metaphors used by some researchers to describe the role of English in Gulf countries reflect ideological perspectives. Troudi and Jendli (2011) speak of the medium of instruction issue as if it is a linguistic war between English and Arabic, where the expansion of English shows an aggressive language whose introduction into the educational system would be catastrophic or detrimental for the Arabic language, both as a vehicle of communication and as a symbol of cultural identity. Another metaphor used in the literature is that of critical discourse analysis that invokes the notion of linguistic hegemony, where English is portrayed as a language with an agency, destroying local cultures and taking their place (Phillipson, 2014). Similarly, Pierre Bourdieu (1999) suggests that any foreign language replacing the mother tongue as MOI carries with it the seeds of linguistic hegemony.

\section{Effect of EMI on achievement, Arabic language, and Arab cultural identity}

Studies that have demonstrated that university students tend to favor using Arabic over English as medium of instruction report that these students believe that Arabic, as a mother tongue, is more natural, more effective, and causes no linguistic or socio-cultural problems for learners (Al-Mashikhi et al., 2014; Ejieh, 2004; Ellili-Cherif \& Alkhateeb, 2015). The research conducted in the Gulf region tends to support these claims. Parents, school principals, and scholars in the Gulf are divided on the issue, especially that they view decisions to use EMI 
and to develop new curricula as symbols of western interference and westernization in the Arab world pushing in the direction of 'More English, Less Islam' (Charise, 2007).

In a study on whether university students saw a negative effect of English as a global language on Emirati culture and identity, 57\% of student (all female), answered with an emphatic 'yes' and 14\% stated they have noticed some changes in the form of "an increased use of English and decreased use of Arabic, a desire to be like English native-speakers" (Hopkyns, 2016, pp. 21-22). The sampling for this study was cluster sampling which included cross-section of forty female students aged eighteen to twenty-four years studying English in the highest level of Academic Bridge Program at Zayed University and divided into three classes. Similar results were obtained by Solloway (2017, 2018). Kuwait University students expressed the same attitude towards the spread of English as a dominant language in a study conducted by Bouhmama and Bouhmama (2015) which was based on a convenience sample of 180 undergraduate students. There, $72.5 \%$ of students held positive attitudes towards Modern Standard Arabic (MSA) as compared to English (36.9\%). The respondents further preferred MSA as a medium of instruction, especially females, who held higher positive attitudes towards MSA as MOI than males did.

Ellili-Cherif and Alkhateeb (2015) investigated the attitudes of college students at Qatar University towards the 2012 policy shift from English to Arabic as MOI in schools and universities. The sample included 295 students at different departments of Qatar University affected by the policy. Participants agreed that both Arabic and English are useful and valued languages for them. But they perceived Arabic as a more efficient and effective language for learning. They expressed their desire to study in Arabic as this would enable them to be more successful in college. Similar findings are reported for Saudi Arabia (Al Zumor, 2019; Al-Qurashi, 1982), Oman (Al-Mashikhi et al., 2014), Libya (Tamtam et al., 2013).

Kirkpatrick (2017) reviewing EMI in East and Southeast Asia, concluded that the negative attitude of higher education learners towards EMI is usually triggered by their low proficiency in English which has affected their achievement in subject matter rather than by any identity or cultural considerations. In fact, in the SESRI (2018) study on Qatari cultural identity, which included answers from 1226 adult respondents and was targeted at Qatari nationals living in residential housing units, Qataris did not think English posed any threats to their culture and identity. Nevertheless, there has been a rising concern over the low proficiency of university students in their native language, Arabic (Guttenplan, 2012). At Northwestern University in Qatar, for example, the students' proficiency in Arabic was considered to be not "at a level that will allow them to work professionally" in media (Guttenplan, 2012). The same holds true at Georgetown University's School of Foreign Service in Qatar where more than half of the students "never get to professional proficiency in their own language." Guttenplan (2012) attributes the low proficiency in Arabic at these two universities to "the rise of English as a lingua franca throughout the Arab world and the consequent decline of Arabic." 


\section{Perceptions of continuing need for English}

Some researchers found that some learners preferred studying in English because of their belief that English is the most frequently used language globally in sciences, business, technology, research, and international communication and the language that could secure better jobs in local, regional, and global markets (Al-Jarf, 2004; Bani-Khaled, 2014; Malallah, 2000; Troudi \& Jendli, 2011). Furthermore, researchers highlighted the role of English language in academic performance at the university (Drennan \& Rohde, 2002; Peiperl \& Trevelyan, 1997). Students with advanced English language skills tend to develop better learning strategies, understand texts they read, and express themselves lucidly (El Massah \& Fadly, 2017; also, Harb \& El-Shaarawi, 2007). Likewise, Al-Issa (2017) conducted a survey among 91 firstyear male and female students aged 17-20 years, registered in an introductory writing courses in an EMI university in the UAE. His findings reported that $57 \%$ of participants in a study of attitudes of UAE University students towards Arabic and English as media of instruction in higher education stated that learners did not feel comfortable writing in Arabic as their education had been mainly in English. However, despite their self-proclaimed weakness in Arabic, 97\% wanted to be literate in Arabic as it is the link to their cultural heritage. Al-Bakri (2013) through semistructured interviews with ten college students and classroom observations of interactions of 85 students and five teachers from Nizwa College of Technology found that Omani college students saw EMI as essential to gain social status and to find a job after graduation. At the same time, they saw no scope for Arabic as MOI due to lack of Arabic content that can be used to teach science and technology classes (see also, Abdel-Jawad \& Abu Radwan, 2011). The situation does not seem to be different in Jordan where the surveys of 250 Jordanian female students from the BA in Applied English program at the University of Jordan demonstrated the overall positive attitudes of the students towards the role of English in their lives (Bani-Khaled, 2014). The same is applicable to Morocco where $94.3 \%$ out of 208 doctoral students from the faculty of Sciences were in favor of EMI in higher education despite their dissatisfaction with their level of proficiency in the language (Belhiah \& Abdelatif, 2016), which runs against Kirkpatrick (2017)'s predication (cited above).

\section{Coexistence of Arabic and English}

A study by Qatar University's Social and Economic Survey Institute (SESRI, 2018), mentioned above, showed that respondents felt that among the prominent elements of Qatari identity are the Qatari vernacular (100\%), religious language in mosques (99\%), and Modern Standard Arabic (99\%). As for language of everyday interaction, respondents felt that not using Arabic in the workplace hurts Arabic (73\%), using English when conversants know Arabic is unacceptable (77\%), and using English in official meetings among Arabs is also unacceptable (68\%). However, 55\% of respondents felt that the presence of a majority of expatriates in Qatar who do not communicate in Arabic is not a threat to Qatari identity. Also, Belhiah and Elhami 
(2015) found that among five hundred students and one hundred instructors from six universities in the UAE participating in the research, the majority see English as a global language, which they have to learn in order to exchange information and interact easily with people from other nations and to get better jobs, while they hold Arabic in high esteem as their mother tongue, the language of the Holy Quran, and a symbol of their identity (see also, Kennetz \& Carroll, 2018). Troudi and Jendli (2011) through administering a five-point Likert scale survey among 110 female students aged 18-22 years at Zayed University in the UAE, found that the students expressed the desire to follow an Arabic-English bilingual approach to instruction.

Pessoa and Rajakumar (2011) examined the impact of Global English on the native language, culture and identity of university students in Qatar. For the study, the researchers surveyed fifty students from Carnegie Mellon University in Qatar and Qatar University and conducted focus group or individual interviews with a sample of the students. They found that for the participants of the study English was significant for professional and educational purposes, while Arabic remained the link that connected them to their culture and religion. While they saw English overtaking Arabic in academia and professional life in Qatar, they did not see EMI as a threat to their Arabic culture and identity. Also, 90\% of respondents indicated that knowledge and use of Arabic will never be lost because of the connection between Arabic and Islam. Outside the Gulf region, Shaaban and Ghaith (2002) investigated language attitudes among students at the American University in Beirut. Their study was based on a probability systematic random sample of 176 students chosen by following a systematic random sampling procedure. The researchers found that in Lebanon, an overall statistically significant difference between low-income and high-income participants at the $\mathrm{p}$ less than .1 in their perception of the vitality of three languages. High-income group accorded both French and English higher vitality (compared to Arabic) than did the low-income group.

It is clear from this review of related literature that discussions about advantages and disadvantages of adopting EMI in higher education are taking place in all countries experimenting with the idea. Two main concerns seem to emerge from research studies on the topic: the low level of proficiency in English of the learners and the faculty and the diminishing roles of the native languages, the symbols of culture and identity.

In the Arab Gulf context, including the Qatari context, people are highly aware of the need for EMI in higher education and are, in the majority, not worried about the adverse effects of EMI on their cultural heritage and national and social identity. However, they feel that the EMI experiment in Qatar was a failure, and they blame that on the low English language proficiency in the country and the lack of proper preparation and involvement of stakeholders in the EFNE initiative. Many also feel that Arabic can easily serve as medium of instruction at all levels of education, but it needs to be strengthened through developing course content in Arabic and improving methods of teaching. The literature also notes an emerging trend that calls for improving the quality of teaching of both Arabic and English, accompanied by the adoption of a bilingual approach the issue of MOI.

The present study will try to answer some of the questions raised in previous research through surveying the opinions of Qatar University students about their 
perceptions and attitudes of the functions of Arabic and English in Qatari society, and more specifically in higher education and their preference regarding the medium of instruction.

\section{Methodology}

The current study was designed with the purpose of examining the perceptions and attitudes of Qatar University (QU) students regarding the utility and vitality of the two main languages operating in the Qatari general communication and education contexts. Data for the study were collected by means of an opinion survey that was filled by a sample of QU students. Below, the details of the participants, the instrument, and data analysis are presented:

\section{Participants}

Of the 861 participants, 53\% were Females and 47\% Males. The nationality distribution was $59.3 \%$ Qatari and $40.7 \%$ Non-Qatari. Of these participants, $14.8 \%$ were monolingual; $74.3 \%$ were bilingual, $8.4 \%$ were trilingual, and $2.5 \%$ spoke 4 or more languages. The sample also included $15.6 \%$ Freshman, 23.1\% Sophomore, $28.7 \%$ Juniors, and $32.6 \%$ Seniors. The areas of specialization were distributed as follows: 40\% Business and Management; 36\% Science and Engineering; 23.5\% Humanities and Social Sciences; and $0.5 \%$ Health Sciences and Medicine. It is worth mentioning that at the time of the survey, all students admitted to these majors were required to demonstrate a certain level of proficiency in English, and with the exception of a couple of majors in Humanities and Social sciences, all of these majors had English as a MOI.

\section{Data collection}

The instrument used in obtaining data for this study is the Subjective Ethnolinguistic Vitality Questionnaire (SEVQ) developed by Bourhis et al. (1981) and modified and used in a study by Shaaban and Ghaith (2002) on the ethnolinguistic vitality of Arabic, English, and French in multilingual Lebanon. The questionnaire is divided into three parts, results of two of which are reported here. The first part consists of demographic information representing factors that may impact the perceptions of QU students of the role of Arabic and English in Qatari society. These factors are gender, area of residence, income, nationality (Qatari vs. non-Qatari), field of specialization, class at the University (Freshman, Sophomore, Junior, or Senior), and number of languages spoken. The second part, on the perceptions and attitudes of QU students, consists of 51 statements regarding five main topics related to language in society, namely, education, cultural identity, workplace, media, and communication.

An excel sheet including the timetable of all undergraduate level courses offered at Qatar University during the Spring 2009 semester was obtained. We followed a quasisystematic random sampling as each tenth course/section on the list was selected. Any 
section whose student enrollment was below 10 was excluded. We believe that this method provided us with a representative sample of undergraduate students of all levels and majors, as confirmed later by the responses we got. Instructors were contacted and arrangements were made for visiting classes and distributing the questionnaire to students. The questionnaire distributed to the respondents was in Arabic rather than English in order to ensure full comprehension of the statements. Students were instructed to return the filled in questionnaire to an address on campus or to send it by email.

\section{Data analysis}

The total number of participants who responded to the questionnaire was 1006; however, $145(14.4 \%)$ cases were excluded. These consisted of cases where participants responded erroneously to questions by entering numbers outside the range of the scale or leaving questions unanswered. The remaining 861 cases $(85.6 \%)$ entered the analysis.

The data were analyzed using SPSS. The internal consistency of the collected data was checked to ensure that the scales used in our questions are reliable. Therefore, we ran the Cronbach's alpha to ensure that different participants were responding to the same questions consistently. Fifty-one scales (corresponding to 51 questions) across 861 participants were inserted into this analysis. The Cronbach's $(\alpha)$ alpha values ranged from 0.689 to 0.861 . The results revealed that the scales had medium to high reliability, suggesting that the scale used across the 51 questions is deemed reliable. The descriptive statistics for all 51 questions and response frequencies were extracted and are shown in the Appendix.

Choosing this method was motivated by the need to identify the determinants of participants' response, hence attitudes. To prepare for investigating determinants or predictors of participants' responses, the Principal Component Analysis was carried out to cluster the questions that are related under one factor, reducing the number of factors entered later into the regression models. Following that, the correlations were run to identify covariance between different factors to exclude those with high covariance from the regression analysis. Finally, the regression analysis was implemented to establish the determinants of participant's responses.

The data was checked for the four assumptions for multiple regression prior to running the regression for each of the 13 models (provided in the Appendix). These assumptions are linearity, reliability of measurement, homoscedasticity, and normality. In each model the independent variables were selected depending on the multicolinearity assumption results, those that are highly correlated $(\mathrm{R}=>0.800)$ were excluded from the model. As for the Dependent variable, it was the responses to the questions per component. The method used in all models is the ENTER model. 


\section{Findings of the study}

\section{Perceptions and attitudes}

\section{Statistical analysis}

The data extracted from the responses of 51 questions by 861 participants were entered into a Principal Component analysis (factor analysis) to categorize all questions into orthogonal factors based on their underlying covariance. The factor analysis (the Principal Component Analysis with Varimax rotation) was carried out to explore the relatedness of the 51 questions to group them into a smaller number of categories, on the basis of the underlying patterns of the correlations among those variables. The sample size and the strength of inter-correlations were suitable statistically. The KMO value was .0877 , and Bartlett's test of Sphericity was significant

Table 1 The 13 components resulting from the factor analysis and their corresponding categories

\begin{tabular}{lllllllll}
\hline Component & \multicolumn{3}{l}{ Questions related } & \multicolumn{1}{l}{ Category } \\
\hline 1 & 13 & 12 & 14 & 10 & 11 & - & - & Media Language Preferences (MLP) \\
2 & 43 & 44 & 46 & 42 & 51 & 40 & 38 & Value and Status of Arabic (VSA) \\
3 & 30 & 50 & 31 & 29 & 35 & 26 & - & Arabic in Education and Society (AES) \\
4 & 23 & 33 & 27 & 1 & - & - & - & Medium of Instruction (MOI) \\
5 & 16 & 17 & 15 & - & - & - & - & Impact of Al-Jazeera Network (IJN) \\
6 & 24 & 25 & 20 & 2 & 21 & 34 & - & English in Scientific and Professional Com- \\
& & & & & & & & munication (ESPC) \\
7 & 19 & 18 & 28 & 41 & - & - & - & Qatari Cultural Identity (QCI) \\
8 & 48 & 49 & - & - & - & - & - & Arabic Books (AB) \\
9 & 9 & 8 & 7 & - & - & - & - & English in Society and Work (ESW) \\
10 & 3 & 4 & - & - & - & - & - & Language in Workplace (LIW) \\
11 & 5 & 6 & - & - & - & - & - & Arabic in Employment (AE) \\
12 & 37 & 47 & 39 & - & - & - & - & Status of Arabic (SA) \\
13 & 45 & 22 & 36 & 32 & - & - & - & Manifestations of Sociocultural identity (MSI) \\
\hline
\end{tabular}

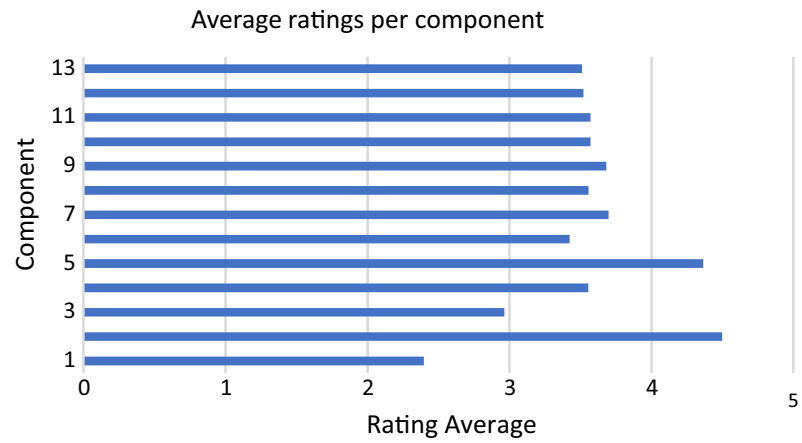

Figure 1 The average ratings for the 13 components 
$(\mathrm{p}=0.000)$. The PCA with Varimax rotation showed that 13 components recorded eigenvalues above 1, explaining a total variance of $58.9 \%$ of the current data, which is considered a respectable percentage in the field.

The extracted 13 orthogonal factors are shown in Table 1 above. On the other hand, Figure 1 shows the average ratings per component.

To identify the predictive power of the relationships between variables, a multiple regression analysis was carried out for all 13 components to check what demographic factors significantly predict the outcome of each component. All data were checked for the requirements of parametric tests and were shown to fulfil the assumptions required by the Multiple Regression procedure. Each component was set as a dependent variable in the model, and all demographic factors were set as independent variables. Table 2 below provides a summary of the statistics of all 13 models and their significance.

The regression models show that only 8 out of the 13 categories were significant. These were Media Language Preference (MLP), Value and Symbolism of Arabic (VSA), Arabic in Education and Society (AES), Medium of Instruction (MOI), Impact of Al-Jazeera Network (IJN), English in Scientific and Professional Communication (ESPC), Qatari Cultural Identity (QCI), and Manifestations of Sociocultural Identity (MSI). These 8 categories account for good percentages of the data in question with the MLP regression model having the highest percentage, namely, $33.1 \%$ of variability in the MLP data, and the Arabic in Education and Society (AES) model having the lowest percentage accounting for $14 \%$ of the variability in the AES data (among the components that reached significance), as shown in Table 3.

The remaining 5 models (Arabic Books (AB); English in Society and Work (ESW); Language in Workplace (LIW); Arabic in Employment (AE); Status of

Table 2 Summary of all 13 models statistics and their significance

\begin{tabular}{lllllll}
\hline $\begin{array}{l}\text { Regres- } \\
\text { sion } \\
\text { model }\end{array}$ & $\begin{array}{l}\text { Component/ } \\
\text { dependent vari- } \\
\text { able }\end{array}$ & R-Square & $\begin{array}{l}\text { \% of data } \\
\text { accounted } \\
\text { for }\end{array}$ & F-value & Model significance & Remarks \\
\hline 1 & MLP & 0.331 & 33.1 & 16.635 & $p<0.000$ & Significant \\
2 & VSA & 0.203 & 20.3 & 5.773 & $p<0.000$ & Significant \\
3 & AES & 0.140 & 14 & 2.690 & $p<0.05$ & Significant \\
4 & MOI & 0.252 & 25.2 & 9.161 & $p<0.000$ & Significant \\
5 & IJN & 0.183 & 18.3 & 4.685 & $p<0.000$ & Significant \\
6 & ESPC & 0.215 & 21.5 & 6.526 & $p<0.000$ & Significant \\
7 & QCI & 0.177 & 17.7 & 4.351 & $p<0.000$ & Significant \\
8 & AB & 0.005 & 0.5 & 0.698 & $p=0.652$ & Not significant \\
9 & ESW & 0.111 & 11.1 & 1.679 & $p=0.123$ & Not significant \\
10 & LIP & 0.014 & 1.4 & 1.912 & $p=0.076$ & Not significant \\
11 & AE & 0.004 & 0.4 & 0.579 & $p=0.747$ & Not significant \\
12 & SA & 0.014 & 1.4 & 1.866 & $p=0.084$ & Not significant \\
13 & MSI & 0.182 & 18.2 & 4.600 & $p<0.000$ & Significant \\
\hline
\end{tabular}


Table 3 Components significantly predicting participants' responses

\begin{tabular}{llllllllll}
\hline Component & \multicolumn{3}{l}{ Questions related } & \multicolumn{3}{l}{ Category } \\
\cline { 2 - 7 } 1 & 13 & 12 & 14 & 10 & 11 & - & - & Media Language Preferences (MLP) \\
\hline 2 & 43 & 44 & 46 & 42 & 51 & 40 & 38 & Value and Status of Arabic (VSA) \\
3 & 30 & 50 & 31 & 29 & 35 & 26 & - & Arabic in Education and Society (AES) \\
4 & 23 & 33 & 27 & 1 & - & - & - & Medium of Instruction (MOI) \\
5 & 16 & 17 & 15 & - & - & - & - & Impact of Al-Jazeera Network (IJN) \\
6 & 24 & 25 & 20 & 2 & 21 & 34 & - & English in Scientific \& Professional Commu- \\
& 19 & 18 & 28 & 41 & - & - & - & Qatari Cultural Identity (QCI) \\
7 & 45 & 22 & 36 & 32 & - & - & - & Manifestations of Sociocultural Identity (MSI) \\
8 & & & & & & & &
\end{tabular}

Arabic (SA)) were not statistically significant and failed to account for a good proportion of the data variability in question.

If we compare the eight significant categories in our study to the seven categories in the study by Shaaban and Ghaith (2003) regarding the perception and attitudes of university students in Lebanon of the utility and ethnolinguistic vitality of Arabic, English, and French in the multilingual Lebanese context, we will find a great degree of overlap. Thus, both studies have the categories Media language use, sociocultural identity, language in society and education, public domain manifestations of sociocultural identity, and language status and symbolism. Shaaban and Ghaith (2003) had two additional categories in which they compare French and English in media use and domains of use.

The current study had three categories related specifically to the Qatari context of the study; these were impact of Al-Jazeera network and its efforts to strengthen the Arabic language, English medium of instruction in scientific and professional studies, and Qatari cultural identity.

\section{Correlations between the 13 categories and the demographic factors}

The regression models above revealed that the significant predictors of the MLP data are (in descending order): number of languages spoken (beta $=.381 ; \mathrm{t}=6.867$; $p<.000)$, nationality (beta $=.300 ; \mathrm{t}=4.616 ; p<.000)$ and gender (beta $=.262$; $\mathrm{t}=4.049 ; p<.000)$. With regard to number of languages spoken, the more languages the participant spoke, the more English was favored. Females favored English more than males, and non-Qataris favored English more than Qataris.

Regarding the VSA, none of the demographic factors reached significance at $p<.000$. However, when question 38, "The English language is highly respected internationally", was removed from the VA data, nationality (beta $=-.142$; $\mathrm{t}=-3.346 ; p<.000$ ) and year of study (beta $=.057 ; \mathrm{t}=3.315 ; p<.000$ ) reached significance. The size of the effect was highest for nationality, then year of study. Qataris agreed more than non-Qataris with statements appreciating Arabic, and senior students agreed more with statement appreciating Arabic. 
Gender $($ beta $=-.284 ; \mathrm{t}=-4.073 ; p<.000)$, nationality $($ beta $=-.288 ; \mathrm{t}=-4.115$; $p<.000$ ), number of languages spoken (beta $=-.270 ; \mathrm{t}=-4.521 ; p<.000$ ) and specialization (beta $=.234 ; \mathrm{t}=2.546 ; p<.000$ ) were significant predictors of MOI. Females agreed more with statement favoring Arabic as MOI, so did Non-Qataris. Multilingual speakers showed little enthusiasm for Arabic as MOI. Business and management students had highest ratings for MOI questions, followed by Science and Engineering students, and finally students of arts and humanities. The ratings from Health and medical students were excluded due to their small numbers.

The only significant predictor of ESPC was Gender (beta $=.335 ; 5.791 ; p<.000$ ). Males agreed more with statement favoring English, so did Multilingual students.

Only gender (beta $=.144 ; \mathrm{t}=3.686 ; p<.000$ ) significantly predicted MSI. Females agreed more with observed dominance of English in Qatari society, but Qataris did not agree with the idea. However, nationality was close to significance (beta $=-.141 ; \mathrm{t}=-2.841 ; p=.01)$.

\section{Language vitality and utility}

Below the means, standard deviations and percentages for the eight significant categories are reported in the form of tables, followed by brief analysis and comments.

\section{Media language preferences (MLP)}

Table 4 shows the preferences of respondents in various aspects of Arabic and English mass media. Results show clear preference for Arabic when listening to music and songs $(60.2 \%)$, following news through newspapers $(72.9 \%)$, reading magazines $(63.7 \%)$, and news broadcasts on radio and television (65\%), as displayed in items $10,12,13$, and 14 below respectively. As for television programs and movies (item 11), students were slightly more in favor of English language media (45.9\%) than Arabic media (31.3\%). Results also showed that females favored English language

Table 4 Media Language Preferences (MLP)

\begin{tabular}{|c|c|c|c|c|c|}
\hline \multirow[t]{2}{*}{ Item Texts } & \multicolumn{2}{|c|}{$\begin{array}{l}\text { Mean \& } \\
\text { Standard } \\
\text { Deviation }\end{array}$} & \multicolumn{3}{|c|}{$\begin{array}{l}\text { Percentages of responses } \\
(\%)\end{array}$} \\
\hline & $\mathrm{X}$ & SD & Disagree & Agree & Neutral \\
\hline 10. I prefer listening to English songs rather than Arabic songs & 2.28 & 1.28 & 60.2 & 17.3 & 22.4 \\
\hline $\begin{array}{l}\text { 11. I prefer watching TV programs and movies in English to } \\
\text { Arabic or Khaleeji songs }\end{array}$ & 3.20 & 1.31 & 31.3 & 45.9 & 22.9 \\
\hline 12. I prefer reading newspapers in English to the ones in Arabic & 2.05 & 1.03 & 72.9 & 8.6 & 18.6 \\
\hline 13. I prefer reading magazines in English to the ones in Arabic & 2.27 & 1.08 & 63.7 & 11.8 & 24.4 \\
\hline $\begin{array}{l}\text { 14. I prefer listening to news broadcasts in English to the ones } \\
\text { in Arabic }\end{array}$ & 2.29 & 1.12 & 65 & 16 & 19 \\
\hline
\end{tabular}


media more than males did and non-Qatari nationals favored English language media more than Qatari nationals.

These expressed media preferences reflect the ecological orientation referred to in EMEMUS in that sociocultural Qatari multilingual context explains the variation in the use of media, as both languages are used in communication, Arabic dominates in news and English dominates in entertainment.

\section{Value and symbolism of arabic (VAS)}

Table 5 relates to the status of Arabic and the value attached to it in Qatari society. Results show that the respondents are extremely attached to the Arabic language and feel that it is deeply ingrained in the Qatari identity. More specifically, respondents expressed their pride in being Arab (92.2\%) and felt that preserving and strengthening Arabic is an act of preservation of Arab culture and identity (92.2\%) because to them Arabic is the best symbol and expression of Arab culture and identity (91.7\%). Furthermore, respondents highly valued Arabic (92\%), felt that those who know their language well deserve great respect (83.7\%), and considered that all Qataris need to master the Arabic language because of its role in their lives (90.7\%). Results also showed that Qatari nationals agreed more than non-Qatari nationals with statements of the value and status of Arabic. Furthermore, senior students agreed more with statements appreciating Arabic than other students. In line with the EMEMUS framework, it is obvious that the respondents see Arabic in the role of language of culture and identity, and they do not see a role for English in this domain.

\section{Arabic in education and society (AES)}

Table 6 Most respondents reported that they like Arabic not only because it is part of the curriculum (54.8\%), do not find the language difficult to learn (45\%), find Arabic literature far from boring (51.8\%), and enjoy reading literature in Arabic (52.3\%). Furthermore, although respondents seemed to enjoy Arabic classes (44.4\%) more than English ones, they seemed to like learning English better than learning Arabic $(45,4 \%)$.

Aside from the high percentage of those who chose the 'neutral' response, it is worth noting that $1 / 3$ of respondents perceived Arabic as difficult to learn, hated Arabic classes, felt Arabic literature was boring, and studied Arabic mainly because it is a requirement. Results also showed that the more languages a student spoke the more he/she favored English to Arabic as school subjects. Along with that, nonQatari nationals favored English to Arabic subjects, while Qatari nationals favored Arabic subjects. Additionally, senior students favored Arabic to English subjects.

In this category, we notice that respondents are attached to their mother tongue and want to be proficient in it, but they realize that the way Arabic is taught makes learning the language less enjoyable than learning English. This clearly shows that though the role of Arabic as a medium of instruction is sought and appreciated, respondents are not satisfied with what EMEMUS calls practices and processes in the current educational system. 


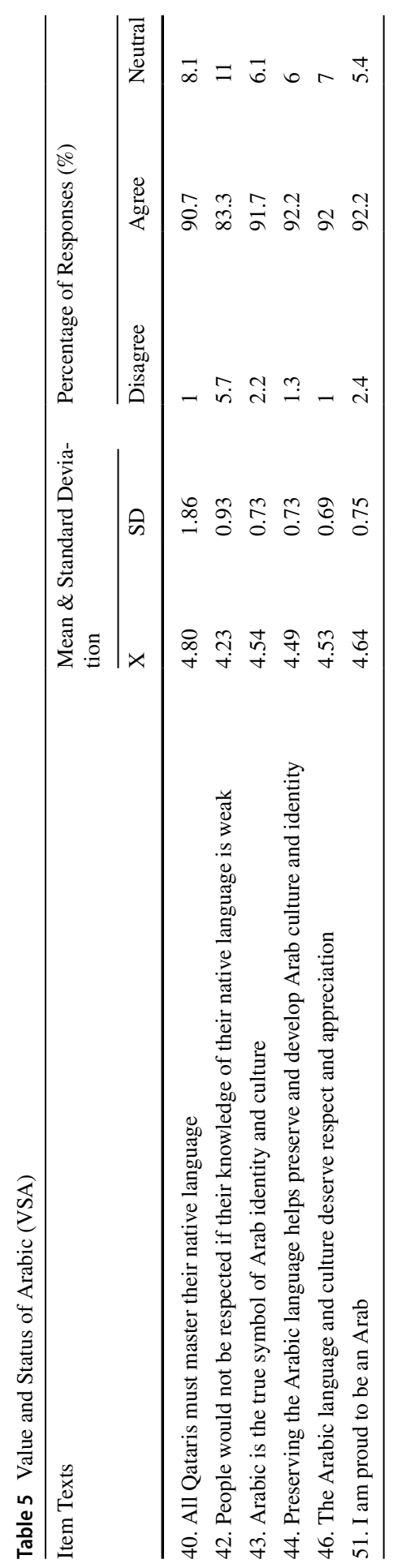




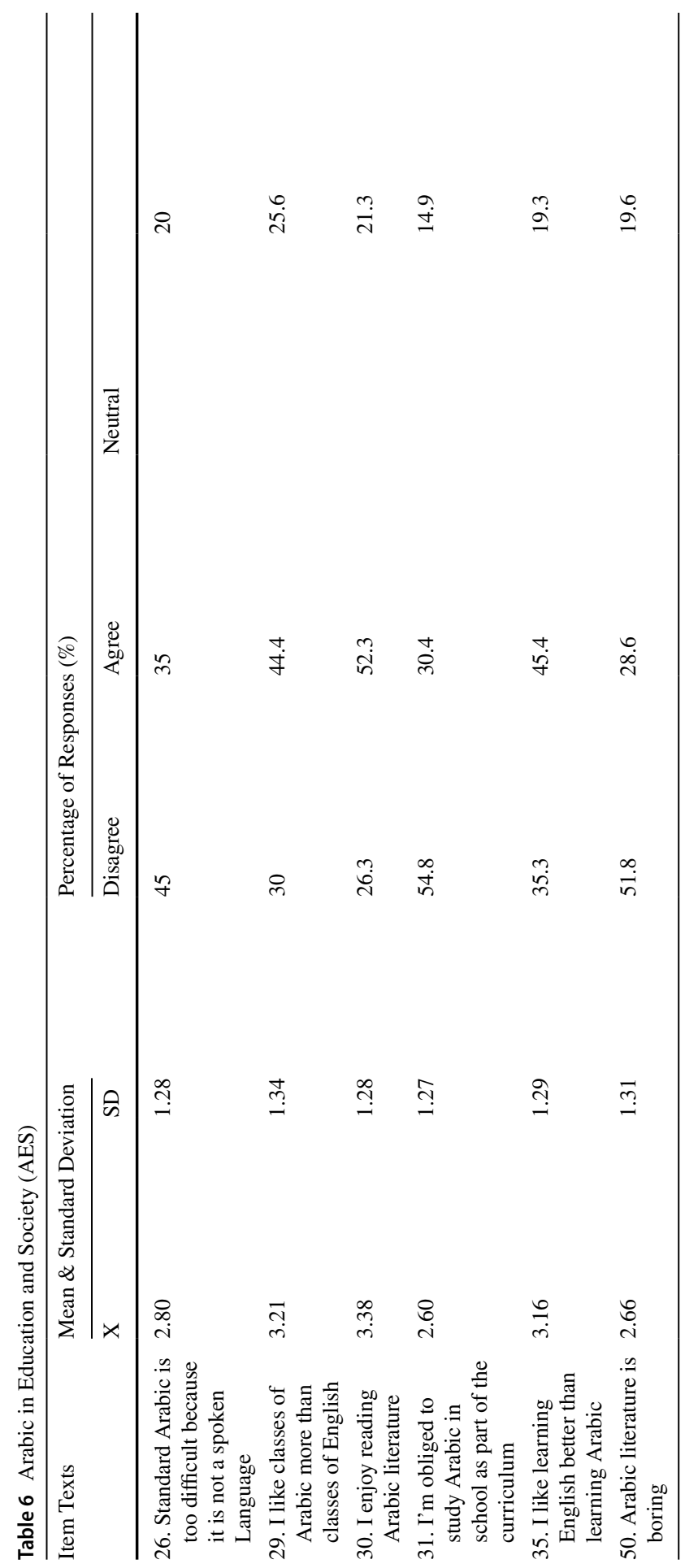




\section{Medium of instruction (MOI)}

Table 7 Results show that respondents expressed their confidence in Arabic as medium of instruction in tertiary education, but at the same time they thought knowledge of English is essential in the modern world. More specifically, respondents were split regarding the suitability of English (36.9\%) and Arabic (41.8\%) to serve as medium of instruction in scientific and professional fields, as displayed in item no. 1. Furthermore, although respondents realized the advantages of studying science and mathematics in English for communication in a globalized world (55.9\%), they believed Arabic could easily serve as medium of instruction in these subjects (70.7\%) and students would learn these subjects better through AMI $(55.3 \%)$. Results also showed that both females and non-Qatari nationals agreed more with statements favoring Arabic while multilingual students agreed less with those statements.

This category shows that the respondents have full faith in the abilities of the Arabic language to fulfill all educational tasks. Yet, they are aware of the power of the EMEMUS component of internationalization and glocalization which suggests that in order for universities to prosper in our globalized world, they need take into account both global and local forces. In this case, it translates into the balanced use of both English and Arabic in higher education in different, and, sometimes overlapping, contexts and domains to meet the needs, abilities, and interests of the learners.

\section{Impact of Al-Jazeera network (IJN)}

Table 8 Results of this category show that respondents are proud of Al-Jazeera and its dedication to the Arabic language and Arab causes (85.4\%), as displayed in item 15 below. Other than that, respondents perceived Al-Jazeera as a major Contributor to the restoration of the prestige of MSA (82.5\%) and to its spread in the Arab world and among Arab communities abroad (77.4\%).

Results also showed that both senior students and non-Qatari nationals agreed more with statements highlighting the positive impact of Al-Jazeera on the development of the Arabic language, while multilingual students agreed less with those statements.

This category reflects satisfaction with and endorsement of the agents et al.Jazeera Network and their management style. Those in charge of Al-Jazeera have set their goal of trying to promote and strengthen the Arabic language in communication and education, and they are fulfilling that.

\section{English in scientific and professional communication (ESPC)}

Table 9 Results show that respondents perceived that English is the preferred language for Qataris as language of communication in science, technology, and business $(80.1 \%)$, as medium of instruction in tertiary education $(67.3 \%)$, as an asset in professional life (63.3\%). Furthermore, results show less enthusiasm for English as an only language of business and technology in the future $(50.7 \%)$, 


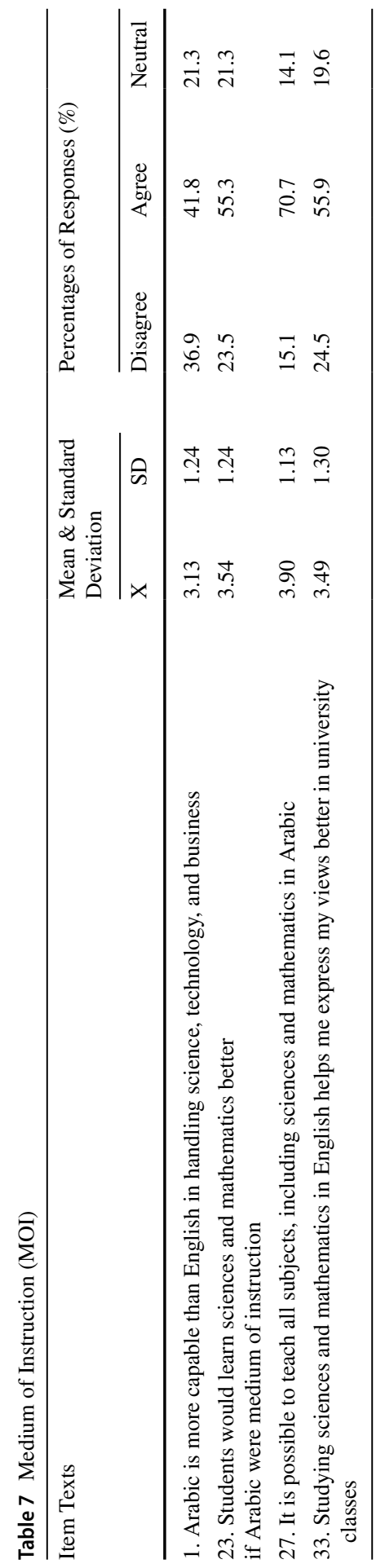




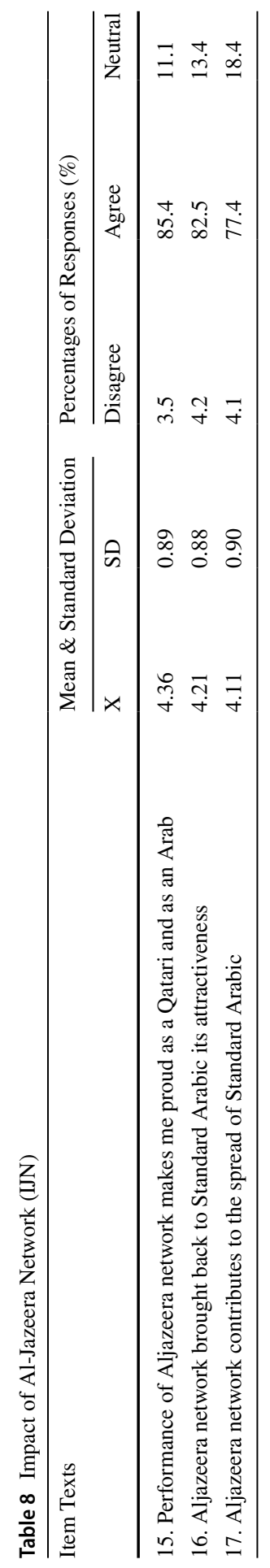




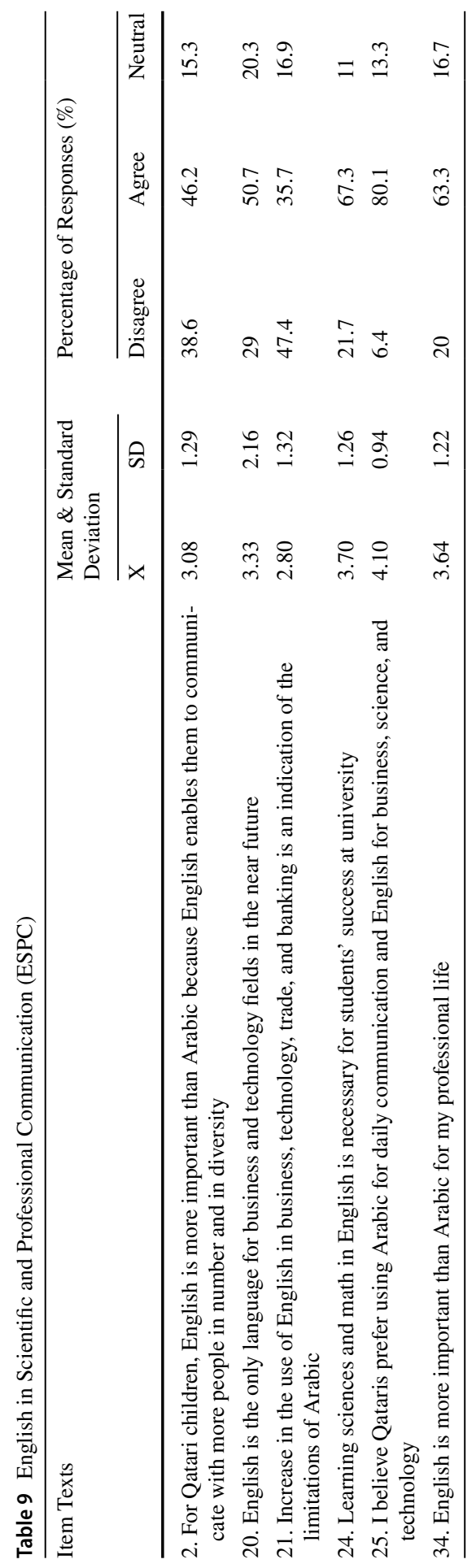


as a means of communication with wider and more diverse audiences (46.2\%), and as an indicator of inability of Arabic to cope with communication needs in business, technology, trade, and banking (35.7\%). The first part (items 24, 25, and 34) reflects the reality of the growing role of English in Qatari education and in workplace communication at the expense of the native language, Arabic. The second part shows how the respondents felt uncomfortable about devaluing the Arabic language as means of daily interaction because to them, as we have seen earlier, Arabic can shoulder all communicative tasks. Results also showed that regarding attitudes towards the utility of languages in scientific and professional life, males and multilingual students agreed more with statement favoring English.

This category shows that respondents see a major role as media of instruction for Arabic and English in higher education. The deciding factor for the choice of the language, according to the EMEMUS framework, is the academic discipline as well as future employability for graduates of the discipline. Graduates of science, technology, business, engineering, and medicine disciplines require higher levels of proficiency in English to function effectively in the workplace and stay up-to-date in their field, compared to graduates of humanities and social sciences who need high proficiency in Arabic and moderate proficiency in English.

\section{Manifestations of sociocultural identity (MSI)}

Table 10 Results show that there is a strong presence for Arab cultural identity (63.3\%) and a relatively strong English cultural identity (53.7\%) in Qatari society as manifested in relevant festivals, musical concerts, sport tournaments, art exhibition, and professional conventions. Withal, respondents reported that Arabic is highly respected and valued in Qatar (62.2\%) even though English enjoys better status than Arabic in social and professional interactions, especially in the private sector $(48 \%)$. It needs to be pointed out, however, that a high percentage of respondents, ranging from $20.1 \%$ to $26.3 \%$ chose 'neuter' as a response. Those who chose 'neuter' may have felt that they could not form a clear opinion about the statements in this category due to lack of knowledge of the issue. Results also showed that females agreed more with statements indicating the dominance of the English identity in the public scene in the Qatari society, while Qatari nationals agreed less with such statements.

This category shows that respondents see clear cultural functions for both Arabic and English in Qatari society, reflecting the multicultural nature of Qatari resident communities that include the indigenous locals and the Arab and foreign expatriates. Some respondents felt alarmed because of the dominance of the English identity and the ratio of expatriates to locals, and the potential effects of these two factors on Qatari cultural identity. 


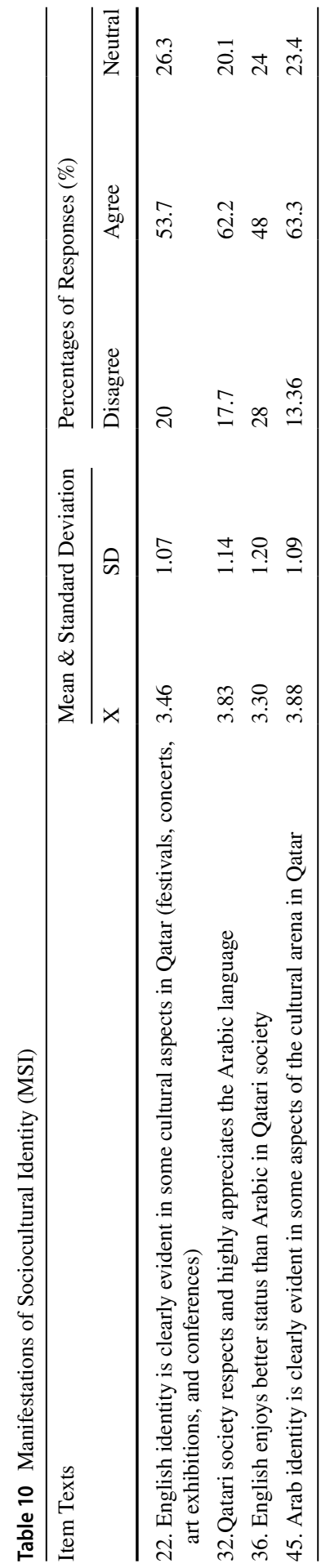




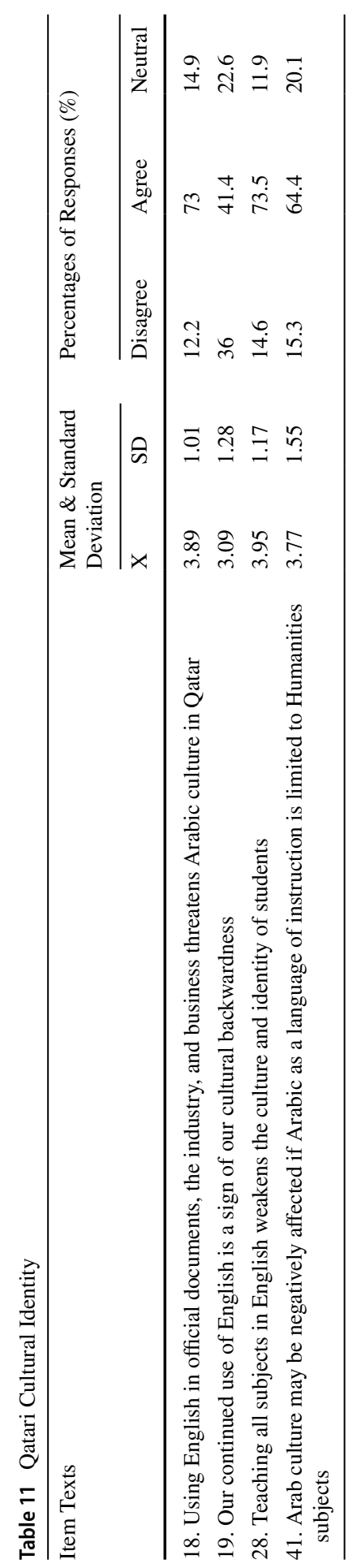




\section{Qatari Cultural Identity (QCI)}

Table 11 Results show that respondents expressed their concern that the increase in the use of English in government, business and industry institutions is threatening the role of Arabic, the official language of the country (73\%) and that the use of English as medium of instruction in all subjects weakens the language, identity, and culture of Qataris (73.5\%). They also expressed displeasure with restricting the use of Arabic as MOI to Humanities as if Arabic is incapable of serving scientific fields, an assumption they refuse as was demonstrated earlier (item 41). Finally, respondents were split on item (19) that states that use of English is a sign of cultural weakness, with $41.4 \%$ in agreement, $36 \%$ in opposition, and $22.6 \%$ neutral. Results also showed that males showed less concern about the threat imposed by English to Arab cultural identity in the Qatari society than their female counterparts.

Results in this category demonstrate that respondents see the intimate relation between language and culture in Qatar. They also feel unhappy about processes and practices, to use EMEMUS terminology, in education and the workplace where Arabic is relegated to a secondary role behind English, a policy that would weaken the sense of national identity for Qataris.

\section{Discussion and conclusions}

The current research study examined the attitudes and perceptions of Qatar University students regarding the utility and vitality of Arabic and English in communication and education in Qatar as well as the determinants of these attitudes and perceptions. More specifically, the study set out to answer two questions related to the perceptions of the utility and vitality of the two languages, and the demographic factors that shape and impact these attitudes and perceptions.

The first question investigated by the current research study related to participants' perceptions of the vitality and utility of Arabic and English in various social, educational, and professional domains. In the Media Language Preferences category, the fact that respondents reported that they prefer Arabic media to English media in listening to music and songs and in following news venues, except in movie and television entertainment, reflect a stronger engagement with Arabic pop culture and Arabic media than with foreign cultures. This might partially explain the preference for AMI over EMI. These results are at variance with the results of Shaaban and Ghaith (2003) where Lebanese respondents showed preference for French and English music and songs, magazines, and movies and television programs over Arabic ones, and with the results of Vaish (2007) where the Tamil, Malay and Chinese Singaporeans predominantly opted for English-language media. However, in both studies in Qatar and Lebanon, Arabic was the preferred language for following news venues (newspapers, radio, and television).

In the Value and Symbolism of Arabic category, the high percentage of responses that show appreciation for the value and symbolism of the Arabic language indicate that Arabic holds a special place in the minds and hearts of Qataris and could explain the dissatisfaction with the decision to replace Arabic by English 
as a MOI in scientific and professional subjects. Similar sentiments towards the mother tongue as a symbol of identity, culture, and religious affiliation have been noted in other studies in the Gulf region (Al-Mashikhi et al., 2014; Badry, 2011; Lindsey, 2012; Pessoa \& Rajakumar, 2011; SESRI, 2018). Generally speaking, the tendency to respect national languages as symbols of national identity is observed globally, with many respondents expressing concern over national languages' potential surrender to English (Doiz et al., 2012; Earls, 2014; Haidar \& Fang, 2019; Hultgren et al., 2014; Jensen \& Thogersen, 2011; Kuteeva, 2014; Muhlhausler, 1996; Saarinen \& Taalas, 2017; Wilkinson, 2012).

In the Arabic in Education and Society category, one reason for participants' preference for Arabic over English and for liking Arabic classes more than English ones is probably the fact that they had studied most subjects in school in Arabic. As for not finding Arabic difficult, in contrast with the overall impression in the Arab world, the closeness of the Gulf dialect to Modern Standard Arabic (Al-Fusha) could provide a reasonable explanation. However, it is important to note that many studies have shown that, despite learners' positive attitudes towards Arabic and claims to proficiency in Standard Arabic, they show high levels of proficiency in the dialect but low level of proficiency in Al-Fusha (Al-Bakri, 2013; Guttenplan, 2012; Troudi \& Jendli, 2011). The problem is that despite the positive attitude towards Arabic, learners show low proficiency in Arabic as was attested to by placement tests at Northwestern and Georgetown universities in Qatar. In Nordic countries and the Netherlands, despite a high number of EMI programs and large exposure to the English-language media, preferences of some students to study in the local languages are explained by the poorer knowledge of academic English and lack of specialized English vocabulary (Hultgren et al., 2014; Jensen \& Thogersen, 2011; Kuteeva, 2014; Wilkinson, 2012). The same results were yielded in the studies of EMI in Pakistan and China (Haidar \& Fang, 2019).

In the Medium of Instruction category, the split in MOI preferences between Arabic and English may be explained by the variation in English language abilities among Qatar University students. Those who come from public schools tend to have low proficiency in English and, therefore, would naturally opt for Arabic while those who come from private/international schools, where learners' proficiency in English is relatively higher, would opt for English. This explanation is in line with findings of other studies in Qatar, the Gulf region and Pakistan (Findlow, 2006; Haidar \& Fang, 2019; Kennetz \& Carroll, 2018; O’Neill, 2014; Pessoa \& Rajakumar, 2011). It must be stressed out that respondents had shown a clear preference for Arabic and a strong attachment to it, as reflected in the rising percentages when it comes to questions that may implicitly cast doubt on the ability of Arabic to serve as MOI for science and business (item 27 in Table 7). Apart from that, results showed that in Pakistan some students expressed preference for EMI due to their wider exposure to English in high schools. However, the Pakistani authorities prefer EMI for a different reason, namely they might not possess resources to provide education in local languages since most knowledge is produced in English (Haidar \& Fang, 2019). The situation is totally different in Singapore-English is the national language of Singapore, overarching the other three-Malay, Chinese, and Tamil, therefore all tertiary education programs with minor exceptions are English (Vaish, 2007). 
In the Impact of Al-Jazeera Network category, it is clear that Qataris in general are proud of Al-Jazeera that has managed to put Qatar on the world map as a key player in Middle Eastern politics. The high percentages in favor of Al-Jazeera and its role reflect the respondents' awareness of the role that widely recognized mass media play in molding public opinion and in pushing and popularizing specific causes. In this case, respondents find that Al-Jazeera has helped revitalize Modern Standard Arabic and brought it closer to its speakers.

In the English in Scientific and Professional Communication category, the first part (items 24, 25, and 34) reflects the reality of the growing role of English in Qatari education and in workplace communication at the expense of the native language, Arabic. The second part shows how the respondents feel uncomfortable about devaluing the Arabic language as means of daily interaction because they feel, as we have seen earlier, that Arabic is capable of shouldering all communicative tasks. Similar results were obtained in the researches on EMI in Europe and Asian contexts, where participants expressed their regret over the impoverished linguistic situations in their countries due to the expansion of English (Doiz et al., 2012; Haidar \& Fang, 2019; Hultgren et al., 2014).

In the Manifestations of Sociocultural Identity category, results show that Qatar is a truly bilingual country where Arabic and English exist side by side and where each language is used for certain domains and functions that are more suitable for its role, and where both languages share some other functions and domains. The presence of foreign communities for whom English is the lingua franca allows not only the English language to flourish but some of its cultural aspects as well. Arabic is the language of the home, identity, culture, and religion while English is the language of the workplace, better employment, and international communication. Such results go in line with the global results, where respondents expressed their feelings about English gaining prominence in educational and professional domains, while the national languages manifest the national pride and used in close circles' communications.

Finally, in the Qatari Cultural Identity category, results indicate that respondents hold Arabic in high esteem as symbol of Arab and Islamic culture and identity. This confirms the finding of the SESRI (2018) survey of Qatari cultural identity. The high value of Arabic in the eyes of the respondents in this study and in similar studies in the Gulf area relates to the fact that Arabic is the language of the Quran and of Islamic religious rituals. In fact, most speakers of Arabic believe that Arabic will never be in danger because it is protected by its connection to Islam (Badry, 2011; Bouhmama \& Bouhmama, 2015; Findlow, 2006; Ronesi, 2011).

It is worth mentioning that since the 2012 decision to revert to Arabic as medium of instruction at Qatar University in Business Administration and Humanities and Social Sciences academic programs, serious steps have been taken to implement the decision, including translating or writing textbooks in these various subjects in(to) Arabic by faculty, using a bilingual approach in teaching to enhance students' knowledge of technical terms in English, and enforcing the use of Arabic in all internal communications in government offices and at QU (Personal Communication with QU Official 2017). 
The second research question was whether there are significant differences in the perceptions of the utility of Arabic and English across the variables of gender, income, area of residence, nationality, field of specialization, and numbers of languages spoken. The findings showed clearly that nationality and gender showed the most robust impact on students' attitude with females and non-Qatari nationals patterning in the same way. That is, these two categories of participants had a favorable attitude towards the English language as a medium of instruction and as a language of media and entertainment. This finding runs against the findings of Bouhmama and Bouhmama (2015) which indicated that Kuwait University female students had a less favorable attitude towards EMI compared to male students. However, the finding is in agreement with studies in places like Turkey, Norway, and Japan where females were found to have more positive attitudes towards EMI and English use in many domains of interaction (Brown \& Sachdev, 2009; Bukve, 2018; Ernesto Macaro \& Akincioglu, 2018).

Notably, sociolinguistic studies have repeatedly shown women to be more sensitive to language change and new linguistic forms (e.g. Labov, 2001). That is, women notice change and adopt it when they find that it would give them prestige. Similarly, females in the current study showed awareness of the dominance of the English language in Qatar, were more positive than their male counterparts towards the use of English in media, and preferred EMI to AMI. Interestingly, in Denmark, compared to elsewhere in the Gulf, one of the crucial factors determining preference for English was the age of the respondents, with younger ones being more positive towards EMI and with no specific breakout for genders (Jensen \& Thogersen, 2011).

Further, in our study, just like females, non-Qatari nationals perceived English as being the dominant language in Qatari society, but they considered it a threat to the Arabic language, nonetheless. On the other hand, the results show that multilingual participants gave higher ratings for English in all domains. This can be explained by the fact that the majority of multilingual participants were those whose first language is not Arabic (e.g. Hindi) and therefore, would most probably not have a special affinity towards the Arabic language. With respect to higher education in particular, the majority of the participants indicated that they saw English as the most important language for their college studies, with a percentage of $66 \%$, which seems to contradict the findings of Ellili-Cherif and Alkhateeb (2015) who concluded that Qatar University students perceived Arabic as a more efficient and effective language for college education. This difference could be explained by the fact that the participants in the current study have all been students who achieved a decent level of proficiency in English as required by the admission conditions of Colleges at QU at the time.

Participants in the study of Ellili-Cherif and Alkhateeb (2015) did not necessarily entertain the same level of proficiency in the English language as the study was conducted post the 2012 decree which exempted students applying to social sciences and humanities colleges and majors (the pool from which the participants of the study were drawn) from English language proficiency requirements. Participants in the study of Ellili-Cherif and Alkhateeb (2015) wanted to do well in college, and they knew that they would do better with Arabic MOI. Nevertheless, these participants agreed with our participants in perceiving English as having a high 
status in Qatar and recognized its significance for professional communication and employability.

Our findings are in line with those of Bukve (2018) who concluded that students with high proficiency in English had more positive attitudes towards English than those with low proficiency. These results are in the same vein with the results obtained for Pakistan, China and European states, where the students expressed worries that their academic English skills might not meet curricula expectations, which will negatively affect their school performance (Brock-Utne, 2001; Haidar \& Fang, 2019; Hultgren et al., 2014; Jensen \& Thogersen, 2011; Wilkinson, 2012).

\section{Concluding remarks}

Applying the EMEMUS conceptual framework to the data in this study clearly showed the complexity of the EMI language policy in Qatar, especially the intersection among the various components of the framework. For example, the role of English is seen essential in education and in the workplace, with QU students agreeing with that role; however, they also stated that Arabic shares this role, and showed resentment for those who refrain from using Arabic in a context where all speak the language. As for the second component, participants felt that the academic discipline should decide which language should be the main MOI. In fact, this is what happens currently, where English dominates in education and the workplace in professional fields and Arabic in humanities and social sciences. However, there are some courses and some work situations where Arabic replaces English and vice versa.

The study also showed the intersection between policy management, agents involved in the process of implementation and evaluation, and practices and processes. The fact that the EMI policy was imposed from the top with little involvement and preparation of agents on the ground resulted in a confusion in practices from English only to Arabic only to classroom codeswitching practices. Students and faculty were not well prepared and not competent enough in English. All this gave rise to explicitly expressed resentment and the ultimate abandonment of the policy. Despite all these issues, students still recognized the value of English for the job market and for acquisition of knowledge and the status and value of Arabic as the symbol of Qatari culture and identity. On the ground, this engendered the current practice of following a bilingual approach in teaching and in instructional material development by faculty.

The following conclusions summarize the major findings of the current study and relate them to current and future policies and practices in the Gulf and other similar contexts in the Arab world and elsewhere.

1. The current study and similar studies carried out in the Gulf indicate that stakeholders feel that the decision to give English a major role in Arab tertiary education is often taken without careful consideration of the potential repercussions of such a decision, such as its impact on the native language and culture, on identity, on social cohesion, and on the achievement of students in subject matter areas serviced by EMI. At present, in the Arab world in general and Gulf 
countries in particular, English is invading all aspects of life in society, especially in the tertiary education arena, where EMI rules supreme. The widespread linguistic shift from Arabic to English in 'the heartlands of the Arab world has been such that there is now an emerging concern for the long-term viability of Arabic in GCC countries' (Piller, 2010).

Apart from this, the rush to adopt EMI without addressing the challenges that the phenomenon has presented to learners could lead to failure of learners to achieve learning outcomes, reduced and limited learner classroom participation and interaction, and reduced motivation (Airey \& Linder, 2008; Al Zumor, 2019; Macaro, 2015; Mustafawi \& Shaaban, 2019; Sert, 2008; Williams, 2015). Therefore, using EMI in higher education requires careful planning and preparation of all stakeholders, especially teachers and students, to ensure that learners possess both critical thinking skills and good proficiency in English (Dearden, 2014; Knagg, 2013).

2. The overall impression is that Arabic is cherished by the majority and has high status and high appreciation in their eyes. Arabic is highly valued as a symbol of individual, social, and cultural identity by the majority of Arabs who see in the relation of language to Islam as a guarantee that no matter how much other languages are used in education and communication, Arabic would survive and thrive in many domains of use (Ababneh, 2016; Bouhmama \& Bouhmama, 2015; Findlow, 2006; Pessoa \& Rajakumar, 2011).

3. We should keep in mind that "making policy is one thing; implementing it is something else entirely" (Thomason, 2001, p. 39). Students coming from public schools in the Gulf, whether they are exposed to English as EMI or as EFL, find it very hard to make the transition to an English-only approach to teaching subject matter at the university. They are strongly in favor of Arabic as a medium of instruction. EMI works best for students coming from English-medium private schools and puts those coming from public schools at a significant disadvantage (Al-Issa, 2017; O’Neill, 2014).

4. Most scholars who have addressed the issue of EMI tend to prefer bilingualism, dualism, or translanguaging as an approach to teaching science and technology subjects (Al Zumor, 2019; Al-Mashikhi et al., 2014; Phillipson, 2015; Thomas \& Collier, 2012). In fact, a large number of students in the study by Al-Mashikhi et al. (2014) proposed the idea of a bilingual approach in the classroom. That way, they could understand and discuss class texts or lectures in Arabic and at the same time learn how to use English technical terms and improve their English a bit. In EMI situations where the students all, or mainly, speak the first language, there is no reason to not develop a bilingual program that will ensure the first language development, English development, and academic development (Crisfield, 2019; Dearden, 2014).

5. Although everyone in the Arab World sees the need for English language education, one major socially based practical issue remains problematic for most Arab societies, that of the disparity in access to quality education between learners from low socioeconomic backgrounds and learners from socioeconomically affluent families. Quality English language education remains the sole property of the elitist, socio-economically able families who can afford to send their children to elitist private and missionary schools while the socioeconomically disadvantaged families 
have to be content with sending their children to public schools, where the whole educational atmosphere leaves a lot to be desired.

Studies have demonstrated that students from public schools where Arabic is the language of instruction find it hard to make the transition to EMI in the university (Al-Issa, 2017; Al-Mashikhi et al., 2014; O’Neill, 2014). This fact explains many students' low English proficiency, negative attitude towards EMI, and preference for using Arabic as a language of instruction in mathematics and science courses. The study showed also that EMI works best for students coming from Englishmedium private schools and puts those coming from public schools at a significant disadvantage.

6. Arabic needs to be strengthened beyond leaving it to the family to keep Arabic alive and vital; parents could help with dialectal Arabic but enhancing Modern Standard Arabic should be the work of schools. Badry (2011) states that "for Arabic to remain part of the identity of young and future generations in the UAE (and elsewhere in the Arab world), the same efforts exerted in teaching English must be brought to bear in improving the teaching of Arabic" (p. 112). Unfortunately, till now, nothing of the sort is taking place. A study by Al-Issa (2017) on the use of Arabic by Emirati university students showed that "while Arabic as a dialect continues to be spoken and used on a daily basis, Arabic literacy is unquestionably losing ground" (p. 3).

\section{Appendix}

\begin{tabular}{|c|c|c|c|c|c|c|c|}
\hline & Statements & $\begin{array}{l}\text { Strongly } \\
\text { disagree } \\
\%\end{array}$ & $\begin{array}{l}\text { disagree } \\
\%\end{array}$ & $\begin{array}{l}\text { neutral } \\
\%\end{array}$ & $\begin{array}{l}\text { agree } \\
\%\end{array}$ & $\begin{array}{l}\text { Strongly agree } \\
\%\end{array}$ & Total \\
\hline 1 & $\begin{array}{l}\text { Compared to English, Arabic is } \\
\text { more capable of handling Sci- } \\
\text { ences, technology and business }\end{array}$ & 8.2 & 29.2 & 21.3 & 24.7 & 16.6 & 861 \\
\hline 2 & $\begin{array}{l}\text { For Qatari children, English is } \\
\text { more important than Arabic } \\
\text { because English enables them to } \\
\text { communicate and talk to more } \\
\text { people in terms of number and } \\
\text { variety }\end{array}$ & 14.7 & 24 & 15.1 & 31.6 & 14.7 & 861 \\
\hline 3 & $\begin{array}{l}\text { Practically, Arabic is less useful } \\
\text { than English for working in most } \\
\text { governmental companies and } \\
\text { offices in Qatar because being a } \\
\text { speaker of only Arabic restricts a } \\
\text { person's chances for promotion }\end{array}$ & 6.6 & 15 & 15.6 & 39.1 & 23.8 & 861 \\
\hline 4 & $\begin{array}{l}\text { Practically, Arabic is less useful } \\
\text { than English for working in most } \\
\text { private companies and offices in } \\
\text { Qatar because being a speaker of } \\
\text { only Arabic restricts a person's } \\
\text { chances for promotion }\end{array}$ & 6.9 & 10.3 & 15 & 43.1 & 24.7 & 861 \\
\hline
\end{tabular}




\begin{tabular}{|c|c|c|c|c|c|c|c|}
\hline & Statements & $\begin{array}{l}\text { Strongly } \\
\text { disagree } \\
\%\end{array}$ & $\begin{array}{l}\text { disagree } \\
\%\end{array}$ & $\begin{array}{l}\text { neutral } \\
\%\end{array}$ & $\begin{array}{l}\text { agree } \\
\%\end{array}$ & $\begin{array}{l}\text { Strongly agree } \\
\%\end{array}$ & Total \\
\hline 5 & $\begin{array}{l}\text { In Qatar, proficiency in Arabic is } \\
\text { more necessary than in English } \\
\text { for getting jobs with high pays }\end{array}$ & 29.2 & 35.9 & 18.7 & 9.3 & 6.9 & 861 \\
\hline 6 & $\begin{array}{l}\text { In Qatar, Proficiency in Arabic } \\
\text { is more important than English } \\
\text { for certain professions in banks, } \\
\text { technology and business sectors }\end{array}$ & 23.2 & 34.1 & 16.9 & 16 & 9.7 & 861 \\
\hline 7 & $\begin{array}{l}\text { Being fluent in English makes a } \\
\text { person feel superior to those who } \\
\text { are not fluent in this language }\end{array}$ & 3.3 & 8.2 & 7.9 & 43.1 & 37.4 & 861 \\
\hline 8 & $\begin{array}{l}\text { It is not possible for a person to } \\
\text { be at a high level in the fields of } \\
\text { sciences, engineering or busi- } \\
\text { ness without being proficient in } \\
\text { English }\end{array}$ & 4.5 & 11.4 & 8.4 & 33.5 & 42.2 & 861 \\
\hline 9 & $\begin{array}{l}\text { You have to be fluent in English } \\
\text { to gain the respect of the outside } \\
\text { world }\end{array}$ & 16 & 21.7 & 17.4 & 26.9 & 18 & 861 \\
\hline 10 & $\begin{array}{l}\text { I prefer listening to English songs } \\
\text { rather than to Arabic songs }\end{array}$ & 36.6 & 23.2 & 22.3 & 10.3 & 7.5 & 861 \\
\hline 11 & $\begin{array}{l}\text { I prefer watching English TV } \\
\text { programs and movies to Arabic } \\
\text { or Khaleeji ones }\end{array}$ & 15 & 16.3 & 22.5 & 26.3 & 19.9 & 861 \\
\hline 12 & $\begin{array}{l}\text { I prefer reading English news- } \\
\text { papers (Peninsula, New York } \\
\text { Times..) to Arabic ones }\end{array}$ & 36.5 & 35.9 & 18.9 & 5.2 & 3.4 & 861 \\
\hline 13 & $\begin{array}{l}\text { I prefer reading English magazines } \\
\text { (Times, News Week..) to Arabic } \\
\text { ones }\end{array}$ & 29 & 34.4 & 24.3 & 7.9 & 4.3 & 861 \\
\hline 14 & $\begin{array}{l}\text { I prefer listening to English news } \\
\text { broadcasts (CNN, BBC, Alja- } \\
\text { zeera..) to Arabic ones }\end{array}$ & 30.1 & 34.7 & 19 & 11.7 & 4.5 & 861 \\
\hline 15 & $\begin{array}{l}\text { The performance of Al-Jazeera } \\
\text { channel makes me proud as a } \\
\text { Qatari and an Arab }\end{array}$ & 1.8 & 1.5 & 10.6 & 27.2 & 58.8 & 861 \\
\hline 16 & $\begin{array}{l}\text { Aljazeera channel brought back to } \\
\text { Standard Arabic its attractiveness }\end{array}$ & 0.9 & 3.3 & 13 & 35 & 47.8 & 861 \\
\hline 17 & $\begin{array}{l}\text { Aljazeera contributes to the dis- } \\
\text { semination of Standard Arabic }\end{array}$ & 1.3 & 2.8 & 18.1 & 35.6 & 42.1 & 861 \\
\hline 18 & $\begin{array}{l}\text { Using English in government docu- } \\
\text { ments, industries, and business } \\
\text { threatens the Arabic culture in } \\
\text { Qatar }\end{array}$ & 1.2 & 10.9 & 14.7 & 41.9 & 31.3 & 861 \\
\hline 19 & $\begin{array}{l}\text { Our continuous use of English is a } \\
\text { sign of our cultural backwardness }\end{array}$ & 11.5 & 24.9 & 22.5 & 22 & 19.2 & 861 \\
\hline 20 & $\begin{array}{l}\text { English is the only appropriate } \\
\text { language for being used in the } \\
\text { business and technology fields for } \\
\text { the near future }\end{array}$ & 10.8 & 18.1 & 19.8 & 32 & 19.3 & 861 \\
\hline
\end{tabular}


Statements

Strongly disagree neutral agree Strongly agree Total $\begin{array}{llll}\text { disagree } \% & \% & \% & \%\end{array}$

$\%$

\begin{tabular}{l}
\hline 21 The increase in the use of English \\
in the fields of business, tech- \\
nology, trade and banks is an \\
indication for the limitation of the \\
Arabic language \\
22 The English identity is clearly \\
evident in some cultural aspects \\
in Qatar (festivals, concerts, Art \\
exhibitions, and conferences)
\end{tabular}

23 Students would better learn Sciences and Math if the language of instruction was Arabic

24 Teaching Sciences and Math in

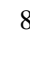

25 I believe that Qataris prefer using Arabic for daily communication and English for business, Sciences and Technology fields

26 The Standard Arabic language is too difficult because it is not a spoken language

27 It is possible to teach all subject including Math and Sciences in the Arabic language

28 Teaching all subjects in English weakens the cultural identity of students

29 I like classes of Arabic more than those of English

5.2

6.6

17.2

$24.7 \quad 30.2$

30 I enjoy reading Arabic literature books

31 I am obliged to study the Arabic language in school only because it is part of the curriculum

32 The Qatari society respects and highly appreciates the Arabic language

33 Studying Sciences and Math in English helps me better express my views when I am at university

34 English is more important than Arabic for my professional life

35 I like learning English better than learning Arabic 


\begin{tabular}{|c|c|c|c|c|c|c|c|}
\hline & Statements & $\begin{array}{l}\text { Strongly } \\
\text { disagree } \\
\%\end{array}$ & $\begin{array}{l}\text { disagree } \\
\%\end{array}$ & $\begin{array}{l}\text { neutral } \\
\%\end{array}$ & $\begin{array}{l}\text { agree } \\
\%\end{array}$ & $\begin{array}{l}\text { Strongly agree } \\
\%\end{array}$ & Total \\
\hline 37 & $\begin{array}{l}\text { The Arabic language is highly } \\
\text { respected internationally }\end{array}$ & 10.5 & 25.1 & 31.9 & 21.4 & 11.1 & 861 \\
\hline 38 & $\begin{array}{l}\text { The English language is highly } \\
\text { respected internationally }\end{array}$ & 0.9 & 1.9 & 11.4 & 30.4 & 55.4 & 861 \\
\hline 39 & $\begin{array}{l}\text { I make an effort to learn the Arabic } \\
\text { language because it is my duty } \\
\text { to master the official language of } \\
\text { my country }\end{array}$ & 3.7 & 9.7 & 21 & 33.8 & 31.7 & 861 \\
\hline 40 & $\begin{array}{l}\text { A native Qatari must master his } \\
\text { country's language }\end{array}$ & 0.4 & 0.6 & 8.1 & 25.3 & 65.5 & 861 \\
\hline 41 & $\begin{array}{l}\text { The Arabic culture might be } \\
\text { negatively affected if Arabic } \\
\text { as a language of instruction is } \\
\text { restricted to Arts subjects (Litera- } \\
\text { ture, History, Geography) }\end{array}$ & 4.8 & 10.8 & 19.8 & 31.7 & 32.9 & 861 \\
\hline 42 & $\begin{array}{l}\text { One would not be respected if } \\
\text { his knowledge of the national lan- } \\
\text { guage of his country is weak }\end{array}$ & 1.0 & 4.6 & 11.1 & 33.7 & 49.6 & 861 \\
\hline 43 & $\begin{array}{l}\text { The Arabic language is the true } \\
\text { symbol of the Arab identity and } \\
\text { culture }\end{array}$ & 0.6 & 1.6 & 6 & 24.6 & 67.2 & 861 \\
\hline 44 & $\begin{array}{l}\text { Reserving the Arabic language } \\
\text { helps the reservation and devel- } \\
\text { opment of the Arab culture and } \\
\text { identity }\end{array}$ & 0.3 & 1.5 & 5.8 & 28.4 & 63.9 & 861 \\
\hline 45 & $\begin{array}{l}\text { The Arab identity is clearly evident } \\
\text { through some aspects of the } \\
\text { cultural arena in Qatar }\end{array}$ & 4.3 & 9 & 23.2 & 38.5 & 25 & 861 \\
\hline 46 & $\begin{array}{l}\text { The Arabic language and culture } \\
\text { are worthy of respect and appre- } \\
\text { ciation }\end{array}$ & 0.3 & 0.4 & 7.2 & 27.7 & 64.4 & 861 \\
\hline 47 & $\begin{array}{l}\text { The Arabic language and culture } \\
\text { are not sufficiently respected } \\
\text { world wide }\end{array}$ & 3.3 & 9.3 & 21.7 & 38.3 & 27.4 & 861 \\
\hline 48 & $\begin{array}{l}\text { There are no books in Arabic on } \\
\text { issues related teenagers or inter- } \\
\text { esting to teenagers }\end{array}$ & 13 & 26.2 & 26.5 & 21.6 & 12.7 & 861 \\
\hline 49 & $\begin{array}{l}\text { There are no books in Arabic that } \\
\text { meet my scientific and cultural } \\
\text { needs }\end{array}$ & 15.4 & 25.1 & 22 & 21.6 & 15.9 & 861 \\
\hline 50 & The Arabic literature is boring & 22.3 & 29.5 & 19.3 & 14.1 & 14.8 & 861 \\
\hline
\end{tabular}




\begin{tabular}{llllllll}
\hline Statements & $\begin{array}{l}\text { Strongly } \\
\text { disagree } \\
\%\end{array}$ & $\begin{array}{l}\text { disagree } \\
\%\end{array}$ & $\begin{array}{l}\text { neutral } \\
\%\end{array}$ & $\begin{array}{l}\text { agree } \\
\%\end{array}$ & $\begin{array}{l}\text { Strongly agree } \\
\%\end{array}$ & Total \\
\hline 51 & I am proud to be an Arab & 1.5 & 1.0 & 5.4 & 13.3 & 78.7 & 861 \\
\hline
\end{tabular}

Funding Open access funding provided by the Qatar National Library.

Open Access This article is licensed under a Creative Commons Attribution 4.0 International License, which permits use, sharing, adaptation, distribution and reproduction in any medium or format, as long as you give appropriate credit to the original author(s) and the source, provide a link to the Creative Commons licence, and indicate if changes were made. The images or other third party material in this article are included in the article's Creative Commons licence, unless indicated otherwise in a credit line to the material. If material is not included in the article's Creative Commons licence and your intended use is not permitted by statutory regulation or exceeds the permitted use, you will need to obtain permission directly from the copyright holder. To view a copy of this licence, visit http://creativecommons.org/licen ses/by/4.0/.

\section{References}

Ababneh, L. (2016). Comparative Arabic and English literacy: A study of female university students' practices in Saudi Arabia. International Journal of Applied Linguistics and English Literature, 5(1), 1-7. https://doi.org/10.7575/aiac.ijalel.v.5n.1p.1

Abdel-Jawad, H. R., \& Abu Radwan, A. S. (2011). The status of English in institutions of higher education in Oman: Sultan Qaboos University as a model. In A. Al-Issa \& L. S. Dahan (Eds.), Global English and Arabic: Issues of language, culture, and identity (pp. 123-152). Peter Lang. https:// www.peterlang.com/view/9783035301205/9783035301205.00007.xml

Ager, D. E. (1996). "Francophonie” in the 1990's: Problems and opportunities. Multilingual Matters.

Airey, J., \& Linder, C. (2008). Bilingual scientific literacy? The use of English in Swedish university science courses. Nordic Journal of English Studies, 7(3), 145.

Al Zumor, A. Q. (2019). Challenges of using EMI in teaching and learning of university scientific disciplines: Student voice. International Journal of Social Sciences \& Educational Studies, 5, 1-17.

Al-Bakri, S. (2013). Problematizing English Medium Instruction in Oman. International Journal of Bilingual \& Multilingual Teachers of English. https://doi.org/10.12785/IJBMTE/010203

Al-Dabbagh, A. (2005). Globalism and the universal language. English Today, 21(2), 3-12. https://doi. org/10.1017/S0266078405002026

Al-Issa, A. (2017). English as a medium of instruction and the endangerment of Arabic literacy: The case of the United Arab Emirates. Arab World English Journal, 8, 3-17.

Al-Jarf, R. (2004). College students' attitudes towards using English and Arabic as a medium of instruction at the university level. Diwan Al-Arab: Manbar Horr li Thakafa Waladab. http://www.diwan alarab.com/spip.php?article748

Al-Mahrooqi, R., \& Denman, C. (Eds.). (2015). Issues in English education in the Arab world (Unabridged). Cambridge Scholars Publishing.

Al-Mashikhi, E., Al-Mahrooqi, R., \& Denman, C. J. (2014). Investigating college of science student attitudes towards using English as a medium of instruction. 99-113.

Al-Obaidli, K. M. (2009). Women ESL teachers' perceptions about their roles and professional development needs in Qatar's education for a new era [Unpublished doctoral dissertation]. University of Birmingham.

Al-Qurashi, K. (1982). The feasibility of the Arabic language as a medium of instruction in sciences [Unpublished $\mathrm{PhD}$ dissertation]. University of Indiana. 
Babault, S., \& Caitucoli, C. (1997). Linguistic policy and education in francophone countries. In R. Wodak \& D. Corson (Eds.), Encyclopedia of language and education: Language policy and political issues in education (pp. 159-167). Springer.

Badry, F. (2011). Appropriating English: Language in identity construction in the United Arab Emirates. In A. Al-Issa \& L. S. Dahan (Eds.), Global English and Arabic: Issues of language, culture, and identity (pp. 81-122). Peter Lang. https://www.peterlang.com/view/9783035301205/9783035301 205.00008.xml

Badry, F., \& Willoughby, J. (2015). Arabic in higher education: Questions of national identity and pragmatism. In F. Badry \& J. Willoughby (Eds.), Higher education revolutions in the Gulf: Globalization and institutional viability. Routledge.

Bakir, M. (2010). Notes on the verbal system of Gulf Pidgin Arabic. Journal of Pidgin and Creole Languages, 25, 201-228. https://doi.org/10.1075/jpcl.25.2.01bak

Bani-Khaled, T. (2014). The role of English as perceived by students of applied English at the university of Jordan. European Scientific Journal, 10(5), 400-420.

Barnawi, O. Z. (2018). Neoliberalism and English language education policies in the Arabian Gulf. Routledge.

Belhiah, H., \& Abdelatif, A. (2016). English as a medium of instruction in Moroccan higher education. Arab World English Journal, 7, 227-238. https://doi.org/10.2139/ssrn.2895569

Belhiah, H., \& Elhami, M. (2015). English as a medium of instruction in the Gulf: When students and teachers speak. Language Policy, 14(1), 3-23. https://doi.org/10.1007/s10993-014-9336-9

Benson, C. (2008). Summary overview: Mother tongue-based education in multi-lingual contexts. In C. Haddad (Ed.), Improving the quality of mother tongue-based literacy and learning: Case studies from Asia, Africa and South America (pp. 1-11). UNESCO.

Bolton, K., \& Kuteeva, M. (2012). English as an academic language at a Swedish university: Parallel language use and the 'threat' of English. Journal of Multilingual and Multicultural Development, 33(5), 429-447. https://doi.org/10.1080/01434632.2012.670241

Bouhmama, D., \& Bouhmama, S. (2015). Attitudes of Kuwait University students towards Modern Standard Arabic (MSA). College Student Journal, 49(3), 466-472.

Bourdieu, P. (1999). Language and symbolic power. Harvard University Press.

Bourhis, R., Giles, H., \& Rosenthal, D. (1981). Notes on the construction of a 'Subjective Vitality Questionnaire' for ethnolinguistic groups. Journal of Multilingual and Multicultural Development, 2, 145-155. https://doi.org/10.1080/01434632.1981.9994047

Brewer, D. J., Augustine, C. H., Zellman, G. L., Ryan, G., Goldman, C. A., Stasz, C., \& Constant, L. (2007). Education for a new era: Design and implementation of K-12 education reform in Qatar. RAND RAND-Qatar Policy Institute.

Brock-Utne, B. (2001). The growth of English for academic communication in the Nordic countries. International Review of Education, 47(3), 221-233. https://doi.org/10.1023/A:1017941523866

Brown, I., \& Sachdev, I. (2009). Bilingual behaviour, attitudes, identity and vitality: Some data from Japanese speakers in London, UK. Journal of Multilingual and Multicultural Development, 30(4), 327-343. https://doi.org/10.1080/01434630902780715

Bukve, T. (2018). Students' perspectives on English medium instruction: A survey-based study at a Norwegian university. NJES Nordic Journal of English Studies, 17, 215-242.

Calvet, L. J. (1987). La guerre des langues et les politiques linguistiques. Payot.

Charise, A. (2007). More English, Less Islam. http://homes.chass.utoronto.ca/ cpercy/courses/eng6365charise.htm.

Christ, H. (1997). Language attitudes and educational policy. In R. Wodak \& D. Corson (Eds.), Encyclopedia of language and education: Language policy and political issues in education (pp. 1-11). Springer.

Crisfield, E. (2019, February 5). Use of L1 in EMI: Understanding why and moving to how. Oxford University Press. https://oupeltglobalblog.com/2019/02/05/use-of-11-in-emi-understand ing-why-and-moving-to-how/.

Cummins, J. (2009). Transformative multiliteracies pedagogy: School-based strategies for closing the achievement gap. Multiple Voices for Ethnically Diverse Exceptional Learners, 11, 38-56.

da Silva, M. (2005). Constructing the teaching process from inside out: How pre-service teachers make sense of their perceptions of the teaching of the four skills. TESL-EJ, 9(2). http://search.ebscohost. $\mathrm{com} / \operatorname{login}$. aspx direct $=$ true $\& \mathrm{db}=$ eric $\& A N=\mathrm{EJ} 1065833 \&$ site $=$ ehost-live $\&$ scope $=$ site $\&$ authtype $=$ sso\&custid $=$ s3704754 
Dafouz, E., \& Smit, U. (2016). Towards a dynamic conceptual framework for English-medium education in multilingual university settings. Journal of Applied Linguistics, 37(3), 397-415. https://doi.org/ 10.1093/APPLIN/AMU034

Dearden, J. (2014). English as a medium of instruction-A growing global phenomenon. British Council.

Despagne, C. (2010). The difficulties of learning English: Perceptions and attitudes in Mexico. Comparative and International Education, 39(2), 55-74. https://doi.org/10.5206/cie-eci.v39i2.9154

Dewaele, J. M., \& Pena Diaz, C. (2018). Sources of variation in Galician multilinguals' attitudes towards Galician, Spanish English and French. Revista Nebrija De Lingüística Aplicada a La Enseñanza De Lenguas, 12, 34-58.

Doiz, A., Lasagabaster, D., \& Sierra, J. M. (Eds.). (2012). English-medium instruction at universities: Global challenges. Multilingual Matters.

Drennan, L., \& Rohde, F. H. (2002). Determinants of performance in advanced undergraduate management accounting: An empirical investigation. Accounting \& Finance. https://doi.org/10.1111/1467629X.00065

Earls, C. W. (2014). Striking the balance: The role of English and German in a multilingual Englishmedium degree programme in German higher education. Current Issues in Language Planning, 15(2), 153-173. https://doi.org/10.1080/14664208.2013.842457

Edwards, J. (1982). Language attitudes and their implications among English speakers. In E. B. Ryan \& H. Giles (Eds.), Attitudes towards language variation: Social and applied contexts (pp. 20-33). E Arnold.

Ehala, M. (2010). Refining the notion of ethnolinguistic vitality. International Journal of Multilingualism, 7(4), 363-378. https://doi.org/10.1080/14790711003637094

Ejieh, M. (2004). Attitudes of student teachers towards teaching in mother tongue in Nigerian primary schools: Implications for planning. Language Culture and Curriculum - LANG CULT CURRIC, 17, 73-81. https://doi.org/10.1080/07908310408666683

El Massah, S. S., \& Fadly, D. (2017). Predictors of academic performance for finance students: Women at higher education in the UAE. International Journal of Educational Management, 31(7), 854-864. https://doi.org/10.1108/IJEM-12-2015-0171

Ellili-Cherif, M., \& Alkhateeb, H. (2015). College students' attitude toward the medium of instruction: Arabic versus English dilemma. Universal Journal of Educational Research, 3(3), 207-213.

Ellili-Cherif, M., \& Romanowski, M. H. (2013). Education for a new era: Stakeholders' perception of Qatari education reform. International Journal of Education Policy and Leadership. https://doi. org/10.22230/ijepl.2013v8n6a438

Fairclough, N. (1995). Media discourse (1st ed.). Bloomsbury Academic.

Fassi-Fehri, A. (2013). Language policy in Arab countries: Searching for a natural, just, democratic, beneficial environment [in Arabic]. Beirut: Dar al-Kitab al-Jadid al-Muttahida.

Ferguson, C. A. (1959). Diglossia. WORD. https://doi.org/10.1080/00437956.1959.11659702

Findlow, S. (2006). Higher education and linguistic dualism in the Arab Gulf. British Journal of Sociology of Education, 27(1), 19-36.

Gardner, R. C. (1985). Social psychology and second language learning: The role of attitudes and motivation. E Arnold.

Garrett, P., Coupland, N., \& Williams, A. (2003). Investigating language attitudes: Social meanings of dialect, ethnicity and performance (1st ed.). University of Wales Press. https://www.jstor.org/stable/j.ctt9qhc23.

Giles, H., Bourhis, R. Y., \& Taylor, D. M. (1977). Towards a theory of language in ethnic group relations. In H. Giles (Ed.), Language, ethnicity and intergroup relations (pp. 307-348). Academic Press.

Griggs, R. A. (2014). Topical coverage in introductory textbooks from the 1980s through the 2000s. Teaching of Psychology, 41(1), 5-10. https://doi.org/10.1177/0098628313514171

Guttenplan, D. D. (2012, June 11). Battling to preserve Arabic from English's onslaught. The New York Times. https://www.nytimes.com/2012/06/11/world/middleeast/11iht-educlede11.html

Haberland, H. (2005). Domains and domain loss. The consequences of mobility: Linguistic and sociocultural contact zones. Institut for Sprog og Kultur.

Haeri, N. (2003). Sacred language, ordinary people: Dilemmas of culture and politics in Egypt. Springer.

Haidar, S., \& Fang, F. (2019). English language in education and globalization: A comparative analysis of the role of English in Pakistan and China. Asia Pacific Journal of Education, 39(2), 1-12. https://doi.org/10.1080/02188791.2019.1569892

Harb, N., \& El-Shaarawi, A. (2007). Factors affecting students' performance. Journal of Business Education, 82(5), 282-290. 
Hopkyns, S. (2016). Emirati cultural identity in the age of "Englishization": Voices from an Abu Dhabi University. In L. Buckingham (Ed.), Language, identity and education on the Arabian Peninsula: Bilingual policies in a multilingual context (pp. 87-115). Multilingual Matters.

Hultgren, A. K., Gregersen, F., \& Thogersen, J. (2014). English in nordic universities: Ideologies and practices. John Benjamins Publishing Company.

Jaworski, A., \& Coupland, N. (2006). The discourse reader (2nd edn). Routledge.

Jenkins, J. (2007). English as a lingua franca: Attitude and identity. Oxford: England.

Jensen, C., \& Thogersen, J. (2011). Danish university lecturers' attitudes towards English as the medium of instruction. Iberica, 22, 13-33.

Karmani, S. (2005a). English, "terror”, and Islam. Applied Linguistics, 26(2), 262-267.

Karmani, S. (2005b). Petro-Linguistics: The emerging nexus between oil, English, and Islam. Journal of Language, Identity, and Education, 4(2), 87-102.

Kennetz, K., \& Carroll, K. S. (2018). Language threat in the United Arab Emirates? Unpacking domains of language use. International Journal of the Sociology of Language, 2018(254), 165-184. https:// doi.org/10.1515/ijsl-2018-0038

Kirkpatrick, A. (2012). English as an international language in Asia: Implications for language education. In A. Kirkpatrick \& R. Sussex (Eds.), English as an international language in Asia: Implications for language education (pp. 29-44). Springer.

Kirkpatrick, A., \& Sussex, R. (Eds.). (2012). English as an international language in Asia: Implications for language education. Springer.

Kirkpatrick, R. (Ed.). (2017). English language education policy in the Middle East and North Africa. Springer.

Knagg, J. (2013). EMI within a global context - Towards a British Council perspective. The Role of English in Higher Education: Issues, Policy, and Practice, 15.

Kramsch, C. (1998). Language and culture (1st ed.). Oxford University Press.

Kuteeva, M. (2014). The parallel language use of Swedish and English: The question of 'nativeness' in university policies and practices. Journal of Multilingual and Multicultural Development, 35(4), 332-344. https://doi.org/10.1080/01434632.2013.874432

Labov, W. (2001). Principles of linguistic change, Volume 2: Social factors. Wiley-Blackwell. https:// www.wiley.com/en-us/Principles+of+Linguistic+Change $\% 2 \mathrm{C}+$ Volume $+2 \% 3 \mathrm{~A}+$ Social+Facto rs+-p-9780631179153

Lara Herrera, R. (2015). Mexican secondary school students' perception of learning the history of Mexico in English. PROFILE Issues in Teachers' Professional Development, 17(1), 105-120.

Larsen-Freeman, D., \& Long, M. H. (1991). An introduction to second language acquisition research. Longman. https://www.academia.edu/35697662/Diane_Larsen_Freeman_Michael_H_Long_An_ introduction_to_second_language_acquisition_research_Longman_1991_

Lindsey, U. (2012, February 7). Debate arises at Qatar U. over decision to teach mainly in Arabic. The Chronicles of Higher Education. https://www.chronicle.com/article/debate-arises-at-qatar-u-overdecision-to-teach-mainly-in-arabic/

Macaro, E. (2015). English Medium Instruction: Time to start asking some difficult questions. Undefined. /paper/English-Medium-Instruction\%3A-Time-to-start-asking-Macaro/ c2d2c2fe55e82545481a7ac123a0634e0b3ccc7a

Macaro, E., \& Akincioglu, M. (2018). Turkish university students' perceptions about English Medium Instruction: Exploring year group, gender and university type as variables. Journal of Multilingual and Multicultural Development, 39(3), 256-270. https://doi.org/10.1080/01434632.2017.1367398

MacLeod, P., \& Abou-El-Kheir, A. (2017). Qatar's English education policy in K-12 and higher education: Rapid development, radical reform and transition to a new way forward. In R. Kirkpatrick (Ed.), English language education policy in the Middle East and North Africa. Springer.

Mahn, H., \& John-Steiner, V. (2012). Vygotsky and sociocultural approaches to teaching and learning. American Cancer Society. https://doi.org/10.1002/9781118133880.hop207006

Malallah, S. (2000). English in an Arabic environment: Current attitudes to English among Kuwait university students. International Journal of Bilingual Education and Bilingualism, 3(1), 19-43. https://doi.org/10.1080/13670050008667698

Marginson, S., \& Rhoades, G. (2002). Beyond national states, markets, and systems of higher education: A glonacal agency heuristic. Higher Education, 43(3), 281-309. https://doi.org/10.1023/A:10146 99605875

Martin, I. P. (Ed.). (2018). Reconceptualizing English education in a multilingual society: English in the Philippines. Springer. 
May, S. (2005). Language rights: Moving the debate forward. Journal of Sociolinguistics, 9(3), 319-347. https://doi.org/10.1111/j.1360-6441.2005.00295.x

Muhlhausler, P. (1996). Linguistic ecology: Language change and linguistic imperialism in the Pacific region. Routledge.

Mustafawi, E., \& Shaaban, K. (2019). Language policies in education in Qatar between 2003 and 2012: From local to global then back to local. Language Policy, 18(2), 209-242. https://doi.org/10.1007/ s10993-018-9483-5

O’Neill, G. (2014). "Just a natural move towards English": Gulf youth attitudes towards Arabic and English literacy. Learning and Teaching in Higher Education: Gulf Perspectives, 11. https://doi.org/10. 18538/lthe.v11.n1.160

Paschyn, C. M. (2013, October 25). Zig-Zagging education policies leave Qatari students behind. AlFanar Media. https://www.al-fanarmedia.org/2013/10/zig-zagging-education-policies-leave-qataristudents-behind/

Peiperl, M. A., \& Trevelyan, R. (1997). Predictors of performance at business school and beyond: Demographic factors and the contrast between individual and group outcomes. Journal of Management Development, 16(5), 354-367. https://doi.org/10.1108/02621719710174534

Pennycook, A. (2010). Language as a local practice (1st edition). Routledge.

Pessoa, S., \& Rajakumar, M. (2011). The impact of English-medium higher education: The case of Qatar. In A. Al-Issa \& L. S. Dahan (Eds.), Global English and Arabic: Issues of language, culture, and identity (pp. 153-178). Peter Lang. https://www.peterlang.com/view/9783035301205/9783035301 205.00008.xml

Phillipson, R. (1992). Linguistic imperialism (1st edn). Oxford University Press.

Phillipson, R. (2014). English, the lingua nullius of global hegemony. The politics of multilingualism: Linguistic governance, globalization and Europeanisation conference, Université de Genève.

Phillipson, R. (2015). English as a threat or opportunity in European higher education. In S. Dimova, A. K. Hultgren, \& C. Jensen (Eds.), English-medium instruction in European higher education (Vols. 3, English in Europe, pp. 19-42). De Gruyter Mouton. https://research.cbs.dk/en/publications/engli sh-as-a-threat-or-opportunity-in-european-higher-education

Piller, I. (2010, December 5). Happy birthday, UAE! Language on the Move. https://www.languageon themove.com/happy.birthday-uae/

Planning and Statistics Authority. (2019). https://www.psa.gov.qa/en/Pages/default.aspx

Robertson R (2018) Glocalization. In International Encyclopedia of Anthropology (pp. 1-8). American Cancer Society. https://doi.org/10.1002/9781118924396.wbiea2275

Romaine, S. (1995). Bilingualism (2nd ed.). Wiley.

Romanowski, M. H., Ellili-Cherif, M., Al Ammari, B., \& Al Attiya, A. (2013). Qatar's educational reform: The experiences and perceptions of principals, teachers and parents. International Journal of Education, 5(3), 119-146. https://doi.org/10.5296/ije.v5i3.3995

Ronesi, L. (2011). Who am I as an Arab English? In A. Al-Issa \& L. S. Dahan (Eds.), Global English and Arabic: Issues of language, culture, and identity (pp. 49-80). Peter Lang. https://www.peterlang. com/view/9783035301205/9783035301205.00008.xml

Ryan, E. B., \& Giles, H. (1982). Attitudes towards language variation: Social and applied contexts (pp. 20-33). E Arnold.

Saarinen, T., \& Taalas, P. (2017). Nordic language policies for higher education and their multi-layered motivations. Higher Education: The International Journal of Higher Education Research, 73(4), 597-612.

Saarinen, T., \& Ursin, J. (2012). Dominant and emerging approaches in the study of higher education policy change. Studies in Higher Education, 37, 143-156. https://doi.org/10.1080/03075079.2010. 538472

Saville-Troike, M. (2002). The ethnography of communication: An introduction (3rd ed.). Blackwell.

Sert, N. (2008). The language of instruction dilemma in the Turkish context. System, 36(2), 156-171. https://doi.org/10.1016/j.system.2007.11.006

SESRI. (2018). National Identity Survey I Qatar University. http://www.qu.edu.qa/research/sesri/datacenter/National-Identity-Survey

Shaaban, K., \& Ghaith, G. (1999). Lebanon's language in education policies: From bilingualism to trilingualism. Language Problems \& Language Planning, 23, 1-16. https://doi.org/10.1075/lplp.23.1. $011 \mathrm{eb}$ 
Shaaban, K., \& Ghaith, G. (2002). University students' perceptions of the ethnolinguistic vitality of Arabic, French and English in Lebanon. Journal of Sociolinguistics, 6(4), 557-574. https://doi.org/10. $1111 / 1467-9481.00201$

Shaaban, K., \& Ghaith, G. (2003). Effect of religion, first foreign language, and gender on the perception of the utility of language. Journal of Language, Identity \& Education, 2(1), 53-77. https://doi.org/ 10.1207/S15327701JLIE0201_3

Skutnabb-Kangas, T., \& Toukomaa, P. (1976). Teaching migrant children's mother tongue and learning the language of the host country in the context of the socio-cultural situation of the migrant family. University of Tampere.

Solloway, A. (2017). English in the United Arab Emirates: Innocuous lingua franca or insidious cultural Trojan horse? In L. Buckingham (Ed.), Language, identity and education on the Arabian Peninsula: Bilingual policies in a multilingual context (pp. 176-196). Multilingual Matters.

Solloway, A. (2018). "Make them take an 'IELTS test' in Arabic"! Resentment of and resistance towards English and English-medium instruction in the UAE. Arab World English Journal, 9, 458-478.

Suleiman, Y. (2013). Arabic in the fray: Language ideology and cultural politics. Edinburgh: Edinburgh University Press.

Taguchi, N., \& Ishihara, N. (2018). The pragmatics of English as a lingua franca: Research and pedagogy in the era of globalization. Annual Review of Applied Linguistics, 38, 80-101. https://doi.org/10. 1017/S0267190518000028

Takahashi, C. (2019). Developing the ideal multilingual self in the era of global English: A case in the Japanese context. The Language Learning Journal. https://doi.org/10.1080/09571736.2019.16062 72

Tamtam, A., Gallagher, F., Naher, S., \& Olabi, A. (2013). The impact of language of instruction on quality of science and engineering education in Libya: Qualitative study of faculty members. European Scientific Journal (ESJ), 9(31), 19-36.

Thomas, W. P., \& Collier, V. P. (2012). Dual language education for a transformed world. Fuente Press.

Thomason, S. G. (2001). Language contact. Edinburgh University Press.

Tilmatine, M. (2015). Arabization and linguistic domination: Berber and Arabic in the North of Africa. In Language empires in comparative perspective (pp. 1-16). De Gruyter. https://hal.archives-ouver tes.fr/hal-02182976

Tollefson, J. W. (2008). Critical theory in language policy. In T. Ricento (Ed.), An Introduction to language policy: Theory and method. Wiley-Blackwell.

Troudi, S., \& Jendli, A. (2011). Emirati students' experiences of English as a medium of instruction. Peter Lang Publishers. https://ore.exeter.ac.uk/repository/handle/10871/25041

Vaish, V. (2007). Globalisation of language and culture in Singapore. International Journal of Multilingualism, 4(3), 217-233.

Wiesing, L. (2016). The philosophy of perception: Phenomenology and image theory (NA Roth Trans). Bloomsbury Academic.

Wilkinson, R. (2012). English-medium instruction at a Dutch university: Challenges and pitfalls. In A. Doiz, D. Lasagabaster, \& J. M. Sierra (Eds.), English-medium instruction at universities: Global challenges (pp. 3-24). Multilingual Matters.

Williams, D. G. (2015). A systematic review of English Medium Instruction (EMI) and implications for the South Korean higher education context. ELT World Online.

Wodak, R., \& Meyer, M. (Eds.). (2002). Methods of critical discourse analysis (1st ed.). Sage.

Publisher's Note Springer Nature remains neutral with regard to jurisdictional claims in published maps and institutional affiliations. 